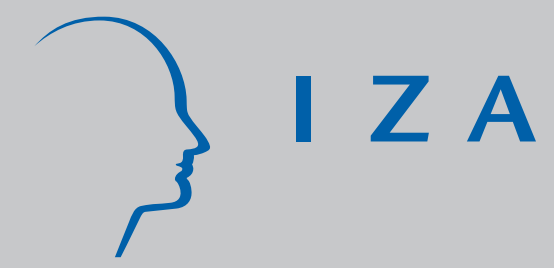

IZA DP No. 1147

Labour Market Flexibility and Employment Protection Regulation in the Baltic States

Raul Eamets

J aan Masso

May 2004 


\title{
Labour Market Flexibility and Employment Protection Regulation in the Baltic States
}

\author{
Raul Eamets \\ University of Tartu and IZA Bonn \\ Jaan Masso \\ University of Tartu \\ Discussion Paper No. 1147 \\ May 2004
}

\author{
IZA \\ P.O. Box 7240 \\ 53072 Bonn \\ Germany \\ Phone: +49-228-3894-0 \\ Fax: +49-228-3894-180 \\ Email: iza@iza.org
}

\begin{abstract}
Any opinions expressed here are those of the author(s) and not those of the institute. Research disseminated by IZA may include views on policy, but the institute itself takes no institutional policy positions.
\end{abstract}

The Institute for the Study of Labor (IZA) in Bonn is a local and virtual international research center and a place of communication between science, politics and business. IZA is an independent nonprofit company supported by Deutsche Post World Net. The center is associated with the University of Bonn and offers a stimulating research environment through its research networks, research support, and visitors and doctoral programs. IZA engages in (i) original and internationally competitive research in all fields of labor economics, (ii) development of policy concepts, and (iii) dissemination of research results and concepts to the interested public.

IZA Discussion Papers often represent preliminary work and are circulated to encourage discussion. Citation of such a paper should account for its provisional character. A revised version may be available on the IZA website (www.iza.org) or directly from the author. 


\section{ABSTRACT \\ Labour Market Flexibility and Employment Protection Regulation in the Baltic States*}

There is increasing pressure for the flexibility of labour markets both in current EU member states and candidate countries. The paper aims to estimate the strictness of employment protection regulation, one of the most relevant aspects of labour market flexibility, and the degree of its actual enforcement, for the Baltic States. For the studies on CEE labour markets the novelty in our approach is that we use information from the applicable legislation as well as on the coverage of labour legislation and the practice of law enforcement. The analysis shows that, though overall EPL strictness is close to the average of EU countries, individual and collective dismissals are relatively heavily and temporary forms of employment relatively weakly regulated. Still, the effective flexibility is increased by larger share of less protected workers and problems with law enforcement, which may be the reason why employers' estimates on the flexibility differ somewhat from the flexibility of formal legislation. The employment protection legislation seems not to have influenced the level of unemployment in the sample of CEE countries. However, it is possible that labour markets of Baltic States will become more rigid if the law enforcement improves, with possible adverse effects on labour market performance.

JEL Classification: J23, J32, J8, K31

Keywords: employment protection legislation, labour market flexibility, Baltic States

Corresponding author:

Raul Eamets

Faculty of Economics and Business Administration

University of Tartu

Narva mnt. 4

Tartu 51009

Estonia

Tel.: +372 7376374

Email: Raul.Eamets@mtk.ut.ee

\footnotetext{
* We acknowledge financial support through the European Union 5th Framework Programme project "The Eastward Enlargement of the Euro-zone (Ezoneplus)" and from the Estonian Ministry of Education and Science. We want to express gratitude for comments made by Alena Nesporova, Karsten Staehr and the participants of Estonian-Finnish Joint Seminar "Economic Integration and the European Union Enlargement" in Tallinn, 22-23 November 2002. The usual disclaimer applies.
} 


\section{Introduction}

The Eastern enlargement of the European Union and the requirements of the European Monetary Union (EMU) increase pressure for flexibility of labour markets both in the current EU member states (EU15) and accession countries. In the framework of EMU and in order to follow the requirements of the optimal currency area (OCA) the growth of labour market flexibility is desirable, because it helps to offset asymmetric shocks, especially when other means such as monetary and fiscal policies are constrained. If labour markets and institutions do not become more flexible, the growth of market disequilibrium is highly probable in both groups. However, the pressure for higher flexibility arises also from the currently high levels of unemployment and low employment levels, and large size of informal economy in transition countries.

One of the most relevant aspects of the multidimensional concept of labour market flexibility is employment protection regulation. It includes employees protection against dismissals, limitations on the use of temporary forms of employment, regulation of working hours, but in a broader sense also health and safety, protection of employees in less favourable conditions. The two opposing perspectives to these regulations were named by Freeman (1993) as "institutionalist" and "distortionist". The former emphasizes that labour regulations are needed to circumvent the weak bargaining power of employees in employment relationships, inadequate insurance against the risk of unemployment, to moderate effects of downswings in aggregate demand and to enhance investments in human capital (and thus productivity growth). The distortionist view emphasizes the advantage of market processes and argues that strict Employment Protection Legislation (EPL) increases dualism of the labour market by favouring insiders (regular workers), increases effective labour costs, discourages hiring and impedes adjustment to economic shocks. So, in order to avoid adverse labour-market outcomes, some trade-off has to be made probably between employment security and labour market flexibility.

Our paper aims to estimate the strictness of employment protection regulation, one of the most relevant aspects of labour market flexibility, and the degree of its actual enforcement, for the Baltic States.

We find it especially relevant to address the issue of EPL within CEE countries. Under a centrally planned economic system workers enjoyed a high degree of employment protection in their jobs (Kuddo 1995). This high degree of employment protection, combined with high wage compression, led to extreme labour rigidity and inefficient labour allocation. Over the 
1990s, the need for rapid structural adjustment of the transition economies after the introduction of economic and social reforms was reflected in drastic amendments to national EPL at the start of economic and social reforms. In CEE countries employment protection laws are not only relevant because of protecting the employees, who are vulnerable partners in employment relationships, but also because trade unions rather weak and often absent in many enterprises.

Further, our special attention is focused on the estimating the rigour of EPL in the Baltic States. Baltic Sates form a special regional cluster. That region has made rather remarkable progress in restructuring the economy, reorienting to new markets and reallocating resources to new sectors, so it is important to investigate, to which extent those developments has been enabled by labor flexibility, how successful has been the building of institutions necessary in market economy and what extent their labor regulations harmonize with those of the EU.

The novelty in our approach is that though several papers discussing labour market flexibility in CEE countries have presented some data on the strictness of applicable legislation, quite a large amount of relevant information has been excluded. We will fill this gap and extend the analyses to the share of workforce covered by regulations, violations of the legal provisions in enterprises and the way law enforcement agencies solve labour disputes.

The empirical analysis of labour laws is based on the methodology developed in various studies of OECD (OECD 1999; Nicoletti et al. 2000). Unfortunately the available aggregate measures of EPL strictness neglect some aspects of the legislation, e.g. the regulation of the use of overtime. In order to analyze the enforcement of regulations, we use data from national labour inspections and courts, the survey of the European Foundation for the Improvement of Living and Working Condition and the worldwide Executive Opinion Survey by the International Institute for Management Development. Throughout the paper comparisons are made with both CEE countries in general and the present EU member countries as we regard those to be the relevant comparison groups.

The paper is structured as follows. In section 2, the notion of labour market flexibility is discussed by distinguishing between macro level flexibility (institutional flexibility, i.e. laws, labour policies and trade unions, and wage flexibility) and micro level flexibility (jobs and workers flows). We also present our own concept of labour market flexibility. In section 3, different approaches towards the measurement of EPL found in literature are reviewed and discussed. In section 4, aggregate indicators of various aspects of employment protection regulation are calculated for the Baltic States and comparisons are made with other countries. 
Section 5 reviews the available evidence on the actual enforcement of labour legislation in Baltic States. In section 6, we look at the impact of labour legislation on labour market performance and how labour legislation interacts with other institutions. The final section concludes.

\section{The concept of labour market flexibility}

From the point of view of general equilibrium theory, perfect flexibility may be understood as a situation where all resources in a given market are allocated in a Pareto efficient way (Hahn, 1998). But it could be also argued whether we treat this term as characterizing a state or a process. It seems to be more appropriate to describe flexibility as a process. For instance, a market is more flexible if it moves towards Pareto efficient resource allocation faster than the other. In principal, it means that we use the framework of the neoclassical equilibrium model and any kind of intervention in the labour market will slow down adjustment speed. So, we can say that labour market flexibility shows how quickly markets adjust to the external shocks and changing macroeconomic conditions.

This definition is very broad and it is very difficult to measure empirically such effects as adjustment speed. Therefore in practical reasons this term has a wide range of applications. For example Treu (1992) considered numerical (or external) flexibility, i.e. the freedom employers enjoy to expand or contract their workforce as they wish and to employ workers on a temporary or part-time basis; working time flexibility, functional flexibility; and pay flexibility.

Nickell (1997) pointed out three aspects of labour market flexibility: employment protection, labour standards and labour policy. The employment protection index was drawn up by the OECD and is based on the strength of the legal framework governing hiring and firing. The labour standards index refers to the strength of the legislation governing a number of aspects of the labour market. Labour policy was divided into active and passive labour policy. Benefit systems were characterized by replacement rate, which shows what share of income is replaced by unemployment benefits, and the duration of these benefits. Active labour market policies refer to expenditures on activities for the unemployed that are geared to help them back into work (labour market training, assistance with job search, subsidized employment and special measures for the disabled).

The most common interpretation of labour market flexibility is connected with labour market regulations and institutions (For example Siebert, 1997; Berthold and Fehn, 1996; Jackmann, 
Layard, Nickell, 1996; Lazear, 1990). For literature overview see also Baker et al 2002. In all OECD countries, there are rules and regulations that govern the employment relationship between workers and firms. Those referring to hiring and firing practices are often referred to as employment protection legislation (Boeri 2000). These rules and regulations govern unfair dismissals, restrictions on lay-offs for economic reasons, compulsory severance payments, minimum notice periods and administrative authorizations

The question of whether and to what extent job security regulations affect labour market flexibility remains a matter of continuing controversy and discussion. Critics have claimed that strongly entered job rights prevent employers from adjusting to economic fluctuation. It also has been alleged that, by preventing layoffs during downturns, strong job security provisions reduce employers' willingness to hire during upturns and thereby contribute to unemployment (OECD, 1999). For instance, if employment protection legislation leads to along- lasting work relationship, it may encourage employers to provide training for workers with potentially beneficial effects for human capital and labour productivity. A better skilled worker may also increase internal (functional) flexibility and thus lead to a better functioning of production activity (Piore, 1986).

Several empirical studies have tried to measure the effect of job security legislation on labour market outcomes. Bentolila's and Saint Paul's (1992) use a "before and after" approach to analyze the Spanish case. They show that labour demand fluctuated more in response to output shocks after flexible employment rules were adopted. If we consider the tightness of the country's employment protection legislation as a proxy for labour market flexibility, we can see that Western European countries have relatively inflexible labour markets (Bertola, 1990; Grubb, Wells, 1993).

In the paper of Baker et al (2002) authors conclude that the empirical findings to not support the common idea of causality of deregulation and better labour market performance. They stress that it is even less evident that further weakening of social and collective protections for workers will have significant positive impact on employment prospects. According to their results the effects of various kind of deregulation on unemployment are very hard to determine and may be quite negligible. 
Next we present briefly our interpretation of labour market flexibility. We argue that labour market flexibility should be measured at two different levels: the macro level and the micro level (see Eamets 2004). The former can be further divided into institutional and wage flexibility. The institutional flexibility of labour market denotes to what extent state institutions and trade unions are involved in the regulation of the labour market. Wage flexibility denotes how responsive wages are to market fluctuations. Micro level flexibility relates to labour market flow analyses. The labour market can be characterized by various flows of workers (transitions between labour market states, occupational mobility and geographical mobility) and by jobs flows (job creation and job destruction.)

Presumably different aspects of flexibility are related to each other. If institutional involvement is very high, workers transition rates are likely to be low. If trade unions are weak, then wages are more flexible etc. Belot and van Ours (2000) analysed in what extend labour market reforms determine unemployment in OECD countries. They examined the relationship between unemployment rate and labour market institutions such as tax rate, replacement rate, employment protection, union density, union coverage, coordination of bargaining. Since they were interested in potential complementarities in institutions and changes in institutions they investigated both direct effects of institutions and interactions between them. They found that particularly interaction effects are important. They concluded that in most countries they observed interaction effects enforce direct effects and for some countries interaction effects were even more important than direct effects.

\section{Employment protection legislation: measurement issues}

Employment protection encompasses any set of regulations, either legal or due to labour contracts, which limit the employers' ability to dismiss a worker immediately or without cost (Pissarides 2001). Here we concentrate on legal measures of employment protection, excluding those called by Betcherman et al. (2001) "collective voice", i.e. voluntary negotiation and administration of the employment relationship via collective representation of workers. The different kinds of employment protection are listed in Table 1. Some of these are designed to cushion the effect of a fall in (labour) demand on employment while others are designed to protect employees from arbitrary dismissals; some regulations imply transfers

\footnotetext{
${ }^{1}$ This phenomenon characterises labour markets in transition economies. The dependence has also opposite direction, if market situation has stabilised, also institutional stability is achieved, then reallocation and restructuring will slow down and finally we can see fewer flows in labour market and less flexibility. In a way we can say that less flexibility shows that restructuring and reallocation (needed for transformation) will soon be over.
} 
from employer to employee (notice and severance pay), the others are like a taxes to be paid to the third party and imposing a deadweight loss (e.g. procedural requirements).

Table 1 The Two Extremes of Employment Protection

RIGID OR PROTECTIVE

Hiring standards

Employer dismissal rights restricted

Substantial severance and notice required

Substantial administrative requirements for

layoff

Fixed term contracting restricted

Temporary agency work restricted

Extra restrictions on collective dismissals
FLEXIBLE OR UNREGULATED

\author{
No hiring standards \\ Unrestricted dismissal rights \\ No severance or notice required \\ Simple administrative procedures \\ Unrestricted fixed term \\ Unrestricted temporary agency work \\ No extra restrictions on collective dismissals
}

Source: Employment protection... 2002

Different indicators have been used in the literature to assess the strictness of EPL provisions. Perhaps the best-known detailed measure is from Lazear (1990): the size of the statutory compensation in case of no-fault individual dismissal for economic reasons. Summary indicators of EPL strictness obtained by compressing the information from a list of detailed indicators greatly facilitate the analysis of employment protection and its effects on labour market performance. The actual construction of such numbers raises difficult choices of quantification and weighting. Both ordinal and cardinal approaches towards aggregating the information have been used. Grubb and Wells (1993) and OECD (1994) constructed the summary indicator by first computing a rank for each of the first level indicators for each country in the sample of countries under investigation, where after calculating the average of these ranks across indicators. The drawback of the method is that if national rankings differ too much across basic indicators, performing cardinal operation in an ordinal measure can lead to unreasonable results. Another drawback is the difficulty of updating the information and evaluating changes in the EPL over a period of time.

In a later study OECD (OECD 1999) developed cardinal summary indicators that allow meaningful comparisons to be made across countries and over time. Since the theoretical analysis emphasizes the analogy of EPL to the taxation on employment adjustment to be paid by employer, the overall intent was to reflect the cost implications of various regulatory provisions for employers. Initially, 22 first level indicators of EPL were converted into cardinal scores, after which various averages were calculated based on these scores. Usually equally weighted averages were used except when a single aspect of EPL was reflected in multiple measures or when some aspects seemed to deserve stronger economic weights than 
the others. So the notice period was deemed be more important than severance payment, and for the measure of overall EPL strictness collective dismissal were allocated only $40 \%$ of the weight for regular and temporary contracts.

In another paper, Nicoletti et al (2000) used for calculating aggregate indicators factor analysis, in which each component of the regulatory framework was weighted according to its contribution to the overall variance in the data. Factor analysis revealed families of detailed indicators that were most associated with different unobserved factors. As a result, countries were "scored" on each of the factors using the estimated weights that were according to the cross-country variance explained by the factor. Individual indicators were aggregated into factors, after which all factors were weighted and summarized into an aggregate indicator. Interestingly, the results provided by this method were almost similar to the results obtained by the ranking of EPL rigour by the method in OECD Employment Outlook.

Researches have also exploited indices based on surveys of employers. The rankings of countries from the International Organization of employers and the EC ad hoc surveys are based on the employers' assessments of the restrictions they face in dismissing workers (OECD 1999). For instance, the International Organization of Employers classifies regulatory constraints as insignificant, minor, serious or fundamental for both regular and fixed-term contracts. Surveys of employers from a rather long list of countries are also included in the economic freedom indexes by World Competitiveness Report, Fraser Institute, the Heritage Foundation/Wall Street Journal and Freedom House (Addison, Texeira 2001). Finally, the most ambitious approach to measure EPL rigor is to calculate the costs of complying with those rule. A step was in this direction was made by Heckman and Pages (2000), who created a job security index, which attempts to measure the expected future cost, at the time of hiring, of dismissing the worker for economic reasons.

Bertola, Boeri and Cazes (2000) emphasised several drawbacks of the existing indicators. First, these do not always capture the role of atypical forms of employment, like overtime work, that may give flexibility if hiring and firing are restricted. Secondly, the present indicators ignore links between EPL and other labour market institutions: firing restrictions would be ineffective, if wages were completely deregulated and employers could reduce them to induce voluntary quits. Thirdly, labour market institutions aim to protect workers against the uninsurable unemployment risk. Protection against job loss arising from EPL is all the more desirable when only scant unemployment insurance is available, and vice versa. 


\section{Labour market regulations in the Baltic States}

This part of the paper assesses the strictness of the labour market legislation in Estonia, Latvia and Lithuania by its effect on labour market flexibility. Generally, the sources of legal regulation of labour relations in the justice system of Baltic States are 1) International conventions, 2) Constitution, 3) Laws 4) Decrees of administrative authorities, 5) Collective agreements. In Baltic States the regulation of employment relations mainly corresponds to international standards, as the more important ILO conventions are mostly ratified and the legislation assures the protection of employees' basic rights concerning work time, remuneration, holidays and termination of contracts, protection of employees in less favourable conditions etc. However, the average number of ratified ILO conventions for Baltic States (37) is well below the numbers of both CEE and EU countries (respectively 62 and 88; see also Table 2).

Concerning laws, most regulations are due to special laws on employment relations (not due to constitution) and labour relations are governed by employment contract (except for those working in civil service $)^{2}$. On the one hand there are several similarities across Baltic States: laws prohibit differential treatment, there exist upper limits for regular working hours, overtime and work during night-time, workers are granted regular vacations and other leaves, termination of employment contracts is subject to restrictions, e.g. obligation to give advance notice, pay compensation etc. In relation to the presence of such provisions, labour legislation in the Baltic States resembles those of the EU countries. On the other hand, there are also some differences. It is to be mentioned that, though labour laws say that more favourable conditions for the employee may be set by collective agreements, the coverage of the latter is in Baltic States less than $20 \%$ compared to the average of both candidate countries (30\%) and EU states (78 \%; Carley 2002), which may affect the average conditions in workers disadvantage.

\footnotetext{
${ }^{2}$ For details see The Republic of Latvia Labour Law [http://www.ttc.lv/en/default-translations-lr.htm]; Republic of Lithuania Law on the Employment Contract [http://www3.lrs.lt/c-bin/eng/]; The Republic of Estonia Employment Contracts Act [http://lex.andmevara.ee/estlex/]
} 
Table 2 Labour legislation and unionization in CEE countries.

\begin{tabular}{|c|c|c|c|c|}
\hline Country & $\begin{array}{c}\text { Number of ILO } \\
\text { conventions } \\
\text { ratified,'31.12.02 }\end{array}$ & $\begin{array}{c}\text { Year of adoption of relevant national } \\
\text { law }\end{array}$ & $\begin{array}{c}\text { Union } \\
\text { density } \%\end{array}$ & $\begin{array}{c}\text { Direct collective } \\
\text { bargaining } \\
\text { coverage } \%^{2}\end{array}$ \\
\hline Latvia & 45 & Labour Code 1972; Labour Law 2002 & 30 & Under 20 \\
\hline \multirow[t]{2}{*}{ Lithuania } & & Law on Employment Contract 1991; & & \\
\hline & 34 & Labour Code 2003 & 15 & $10-15$ \\
\hline Estonia & 31 & Employment Contracts Act 1992 & Under 15 & 29 \\
\hline Baltic's & 37 & - & 20 & 20 \\
\hline CEEC & 62 & - & 25.8 & 45.2 \\
\hline EU15 & 88 & - & 43.8 & 78 \\
\hline OECD & 73 & - & & \\
\hline USA & 14 & & 13.5 & 15 \\
\hline
\end{tabular}

Source: Carley 2002.

1. Percentage of salaried workers that belong to a union

2. The proportion of workers that have their pay and conditions set, at least to some extent, by collective agreements.

We will estimate the strictness of EPL in three areas: working under regular employment, regulation of temporary forms of employment and regulation of collective dismissals for the state of legislation in year 2002. As at least in some transition countries labour legislation is frequently changed, also the variation over time is checked for. The analysis regards the termination of employment relationship at the will of the employer for economic reasons, in case of voluntary quits these regulations (e.g. statutory compensation payments) are not applied. But at least for Estonia there is lots of anecdotal evidence that employers force involuntary quits to be processed as quits due to agreement of parties, in this way avoiding these regulations.

The $\mathrm{WLB}^{3}$ survey has also observed the possibility that since by law employment contracts are to be concluded in written form, the employee and employer could sign an extra agreement by which employee resigns some of his/her benefits for the employers benefit. As an example of such contract could be a notice of dismissal (voluntary leave) signed by employee and left with the employer with open date. The frequency of making such an extra agreement declined in Estonia from $10 \% 1998$ to 6 \% 2002. Contrary, Latvia and Lithuania observed the opposite trend: share of such contracts has increased from $6 \%$ to $9 \%$ in Latvia and from $4 \%$ to $9 \%$ in Lithuania inn respective years. However, Antila and Ylöstalo (2002) argued that since many (15\%) people declined to answer the question about the presence of such agreements, and those answering the question were generally satisfied with the content of agreement, the actual frequency of extra agreements could be even higher on account of

\footnotetext{
${ }^{3}$ Working Life Barometer in the Baltic Countries 2002 and 1999 by the Finnish Ministry of Labour (See Anttila and Ylöstalo, 2002)
} 
those declining to answer.

The data used in calculations for Baltic States is given in Appendix 1. The data and calculations for other countries are from Riboud et al. (2002) and OECD (1999). We note that in the Baltic countries these regulations do not apply to civil servants, while their status is regulated with separate laws and employment contracts shall not be concluded with them4. There exist both special hiring restrictions (for who can be in the civil service, concerning citizenship, possession of official language, education, age) as well as special firing restrictions (higher statutory severance payments in case of dismissal in Estonia, max 12 month). Aside to dismissals regulations there are also some other regulations, concerning wages, leaves, training at the expense of employer and limited ability to work elsewhere. So the status of public servants is more heavily regulated than the status of employees working under employment contract.

One of the more frequently used detailed indicators of individual dismissals is the length of the advance notice period and the severance pay required (as used in Lazear (1990). In the first columns of table 3 the sum of the maximum severance pay and notice period are presented. These are higher for Lithuania and Estonia, compared with Latvia;, in general employees with longer job tenure enjoy a higher level of protection (see Appendix 1). The averages of Baltic, CEE and EU countries are broadly similar. However, in order to assess the information included in detailed indicators and to compare the strictness of the regulation of labor relations across the Baltic States and EU countries we next present summary indicators of employment protection regulation.

Table 3 Indexes of regulation of unlimited duration employment contracts (late 1990's)

\begin{tabular}{|c|c|c|c|c|c|c|c|c|c|}
\hline \multirow[t]{2}{*}{ Country } & \multirow{2}{*}{$\begin{array}{l}\text { Max. pay } \\
\text { and notice } \\
\text { period } \\
\text { (month) }\end{array}$} & \multicolumn{4}{|c|}{ Index of Nicoleti et al. (2000) } & \multicolumn{4}{|c|}{ Index of OECD (1999) } \\
\hline & & $\begin{array}{c}\text { Procedural } \\
\text { inconveniences }\end{array}$ & $\begin{array}{l}\text { Direct } \\
\text { firing } \\
\text { costs }\end{array}$ & $\begin{array}{c}\text { Notice } \\
\text { and } \\
\text { probation } \\
\text { period }\end{array}$ & $\begin{array}{c}\text { Overall } \\
\text { strictness }\end{array}$ & $\begin{array}{c}\text { Regular } \\
\text { procedural } \\
\text { inconveniences }\end{array}$ & $\begin{array}{l}\text { Notice } \\
\text { and } \\
\text { everance } \\
\text { pay }\end{array}$ & $\begin{array}{l}\text { Difficulty } \\
\text { of } \\
\text { dismissal }\end{array}$ & $\begin{array}{c}\text { Overall } \\
\text { strictness }\end{array}$ \\
\hline Latvia & 5.0 & 1.9 & 3.5 & 2.7 & 2.6 & 1.0 & 2.0 & 4.0 & 2.3 \\
\hline Lithuania & 14.0 & 1.6 & 4.7 & 3.7 & 3.1 & 1.0 & 4.4 & 3.8 & 3.0 \\
\hline Estonia & 8.0 & 2.6 & 4.0 & 3.8 & 3.3 & 2.0 & 3.4 & 3.8 & 3.1 \\
\hline Baltic's & 9.0 & 2.0 & 4.1 & 3.1 & 3.1 & 1.3 & 3.3 & 3.8 & 2.8 \\
\hline CEEC & 7.8 & 2.1 & 3.4 & 3.5 & 2.9 & 2.1 & 2.0 & 4.0 & 2.5 \\
\hline EU15 & 9.5 & 2.4 & 2.0 & 3.3 & 2.7 & 2.2 & 2.0 & 3.0 & 2.4 \\
\hline USA & 0 & 0.0 & 0.4 & 0.0 & 0.1 & 0.0 & 0.0 & 0.5 & 0.2 \\
\hline
\end{tabular}

\footnotetext{
${ }^{4}$ The Republic of Latvia State Civil Service Law (01.01.2001); Public Service Act (01.01.1996); The Republic of Lithuania Law on Public Service (08.06. 1999).
} 
The calculations were made according to the method in OECD 1999 Employment Outlook as well as the method developed by Nicoletti et al. (2000). The calculation of the indices proceeds as follows. First, each of the detailed indicators is converted into scale from 0 to 6 . Scaled indicators are weighted and added together to $2^{\text {nd }}$ level indicators. Concerning regular (unlimited) contracts, in the OECD 1999 method there are three 2nd level indicators, procedural requirements, notice and severance pay, and difficulty of dismissal. In index of Nicoletti et al. (2000) information is aggregated into 3 factors: procedural inconveniences, direct firing costs and notice and probation period. For the first method the index of overall strictness of regulation is a simple average of three 2 nd level indices, for the second method factors are weighted. The final measure varies from 0 to 6 ; low value indicates flexible EPL and high value strict legislation.

The second area analyzed is the usage of temporary forms of employment, which includes fixed-term contracts and temporary work agency (TWA) employment. For both, there are considered "objective" reasons under which a fixed-term (or TWA) contract could be offered (seasonal work, replacement of temporary absent permanent workers etc), the maximum number of successive renewals and the maximum cumulated duration of the contract.

Third, in several European countries there are extra (additional) regulations applied in the case of collective redundancies on top of those for individual dismissals ${ }^{5}$. It is important to consider collective dismissals regulations separately since the ranking of countries may be quite different (OECD 1999), however most indices (including Nicoletti (2000)) have neglected these. The OECD (1999) study considered four issues: the minimum number of dismissed employees for the dismissal to be collective, additional notification requirements (where employee representatives or government authorities need to be informed), additional delays involved in addition to individual dismissals and other special costs to employers (e.g. additional severance pay).

The table below summarizes all previous information into the highest level EPL indicator. The summary indicator of Nicoletti (2000) is an average of regular and temporary employment indices. For the OECD 1999-year index version 2, regular and temporary employment indices have weights $5 / 12$ both and collective dismissals have weight $1 / 6$ as they represent only incremental restrictions on top of the restrictions on individual dismissals. The table reveals that in Baltic States EPL strictness is close to the EU average level; the latter that is actually quite high compared with many other developed countries (e.g. the USA). Despite

\footnotetext{
${ }^{5}$ The 1975 EC Directive on collective redundancies has shaped EU member states legislation in this area.
} 
the differences in most of the detailed indicators, the overall EPL strictness seems to be not very different across the Baltic States (In Latvia the regulation possibly a bit more favourable to employers); compared with other CEE countries the EPL regulation is in all 3 areas slightly stricter in the Baltic States. Two different methods for aggregating detailed indicators into aggregate indices have lead to a more or less similar conclusion that causes no surprises, given the results of the OECD (1999) and Nicoletti et al. (2000).

Table 4 Summary indicators of the strictness of the employment protection regulation

\begin{tabular}{|c|c|c|c|c|c|c|c|c|c|}
\hline \multirow[t]{3}{*}{ Country } & \multirow{3}{*}{ 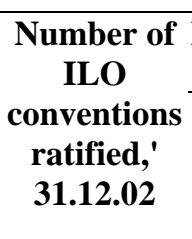 } & \multicolumn{3}{|c|}{ Index of Nicoletti et al. (2000) } & \multicolumn{5}{|c|}{ Index of OECD (1999) } \\
\hline & & Regular & Temporary & & Regular & Temp. & Collective & Overal & EPL rigour \\
\hline & & contracts & comtracts & $\begin{array}{l}\text { EFL } \\
\text { rigour }\end{array}$ & contracts & Contracts & s alsmissals & Value & $\begin{array}{c}\text { Rank in CEE } \\
\text { countries }\end{array}$ \\
\hline Latvia & 45 & 2.8 & 3.2 & 3.3 & 2.3 & 2.1 & 4.0 & 2.5 & 6 \\
\hline Lithuania & 34 & 1.8 & 1.1 & 1.1 & 3.0 & 1.4 & 4.9 & 2.7 & 4 \\
\hline Estonia & 31 & 2.3 & 2.2 & 2.2 & 3.1 & 1.4 & 4.5 & 2.6 & 5 \\
\hline Baltic's & 37 & 2.8 & 3.2 & 3.3 & 2.8 & 1.6 & 4.5 & 2.6 & - \\
\hline $\begin{array}{l}\text { CEEC } \\
\text { average } \\
\text { CEEC var. }\end{array}$ & 62 & 2.5 & 0.8 & 1.7 & 2.7 & 1.2 & 4.1 & 2.4 & - \\
\hline coeff. & $31 \%$ & $25 \%$ & $125 \%$ & $47 \%$ & $16 \%$ & $87 \%$ & $12 \%$ & $24 \%$ & - \\
\hline EU15 & 88 & 2.4 & 2.3 & 2.4 & 2.6 & 2.3 & 3.2 & 2.5 & - \\
\hline OECD & 73 & & & & & & & & - \\
\hline USA & 14 & 0.1 & 0.3 & 0.2 & 0.2 & 0.3 & 2.9 & 0.7 & - \\
\hline
\end{tabular}

Source: authors' calculations; Nicoletti et al. (1999); OECD (1999); Riboud et al. (2002)

In CEE countries, generally, the overall EPL strictness is close to the average EU level, too the value for EU is 2.5 compared to the average of 2.4 in nine CEE countries (the three Baltic States, Poland, Hungary, Slovakia, the Czech Republic, Slovenia, Bulgaria). That is because in the 1990s transition countries have established various forms of employment protection legislation similar to continental European countries and rejected Anglo-Saxon "hire at will" industrial relations, so that by the end of the 1990s, regulations broadly resemble those found in the EU countries (Riboud, Sanchez-Paramo, Silva-Jauregui 2002). Although there are still some steps to be taken to enforce the labour law acquis in certain areas (e.g. gender equality, transposition of EU directives) in some (including Baltic) countries, in general the alignment of labor regulations with the EU labor law acquis (e.g. adopting directive on collective redundancies - 98/59/EC), has mostly advanced well ${ }^{6}$.

\footnotetext{
${ }^{6}$ Baltic States have made steps towards harmonizing labor regulations with EU requirements, still steps are yet to be made for enforcement of Acquis Communautaire in labor law. For Estonia the report of European Commission noted that although Estonian legislation is to a large extent in line with the acquis, some progress is to be made in gender equality, prohibition of discrimination, information and consultation of workers (Regular Report on Estonia's... 2002). For Latvia the alignment is well advanced (the new labour code in effect since June 2002 transposed majority of the labour law acquis) but efforts are required in order to adopt directives
} 
Not all components of EPL contribute equally to the cross-country variation of strictness. In Latvia dismissals are less regulated than in Estonia and Lithuania; the Baltic States' average is higher than that of EU (2.8 versus 2.4), i.e. dismissals do not seem to be less regulated in the former. Similarly to other CEE countries, the norms in Baltic States consist rather of transfers between the employers and the employees (direct firing costs index is 3.8 index for the Baltic States and 2 for the EU countries) than of taxes to be paid to the third party (procedural inconveniences index is 1.3 for the Baltic States and 2.2 for the European Union) that impose a deadweight cost, that is a positive side of labour laws in CEE countries.

The usage of temporary employment is significantly less restricted in the Baltic States and CEE compared to EU (the values of OECD (1999) indexes are 1.6, 1.2 and 2.3). In Lithuania and Estonia the use of temporary employment is less restricted than in Latvia. The low value of the index is mostly due to the lack of regulations on the use of temporary work agencies in most CEE countries. Though law allows the use of fixed term contracts for short-term temporary work only, at least in Estonia fixed term contracts are often used for non-temporary work as well, that raises the issue of enforcement.

In all Baltic Countries the regulation of collective dismissals is even stricter than the EU average in the EU countries (see Table 4) mainly due to the notification requirements and additional delay periods. In Estonia some of the recent changes in legislation applicable since 2002 have made collective dismissals more costly, increasing the value of the index from 2.6 to 4.5 , however others have decreased it, in particular, the severance payments in case of collective dismissals are now covered not by employers but by the unemployment insurance fund. Indeed, many enterprises postponed their dismissals till the coming into force of those provisions.

In sum, the labour regulations may have, at least in some respect, a negative effect on labour market flexibility of the Baltic States. On the other hand, the Baltic countries have already made most of the progress on the way towards harmonizing labour regulations with EU requirements, and although some steps are still to be taken, no big changes are expected in the short term, consequently no adverse impacts on labour market flexibility is expected due to membership of the EU in 2004.

regarding information and consultation of workers and amendments to Labour Dispute Law, enforce acquis in the gender equality and the acquis in health and safety at work (Regular Report on Latvia's... 2002). Lithuania has reached an advanced stage in the area of labour law (the new Labour Code valid since June 2002 transposes the bulk of labour law acquis), still several directives need to be transposed (directives of European Works Council, posting of workers, the right to information and consultation of workers; Regular Report on Lithuania's... 2002). 


\section{The enforcement of EPL}

All the existing papers on the topic of labour market flexibility in CEE countries that we are aware of (among them, Cazes 2002, Svejnar 2002, Riboud et al. 2002, Orenstein and Wilkens 2001) have focused on the discussion of the strictness of formal legislation (measured by the OECD EPL strictness index), and neglected to analyze factors influencing the actual enforcement of these regulations. Even quite strict labour laws may have little influence on the economy, if economic agents violate them, if law enforcement agencies are weak or if these laws cover only a small proportion of the total workforce. For instance, it has been argued that interventions labor codes in many developing countries are balanced by institutional limitations and economic structure (Betcherman et al. 2001). These issues may be relevant also for the transition economies. We need now to close this gap in the literature and present some evidence concerning, how strictly the formal regulations are applied in practice and how this might influence labour market flexibility.

\subsection{Employment status and employment protection legislation}

It matters for EPL strictness, which a proportion of the workforce is actually covered by the regulations: c.p., a higher proportion of the workforce on regular employment means less flexible labour markets. Hereby we review the actual usage of different types of employment contracts (contracts without limit of time, fixed term contracts etc.) in the Baltic States compared with CEE and EU countries. The information is presented in Appendix 4. Previous studies have showed that stricter EPL is associated with higher shares of self-employment (OECD 1999). Comparing the average numbers of Baltic States with the EU countries' data we see the density of self-employment is rather similar (respectively $14.5 \%$ and $16.6 \%)^{7}$. Figure 1 reveals that between CEE countries stricter overall EPL is not associated with higher a share of self-employment.

\footnotetext{
${ }^{7}$ It is important to notice that Baltic States are not homogeneous in respect to self-employment. In Lithuania the share of self-employment in total employment is $19 \%$ (due to high agricultural employment) while in Estonian it is only $10 \%$
} 

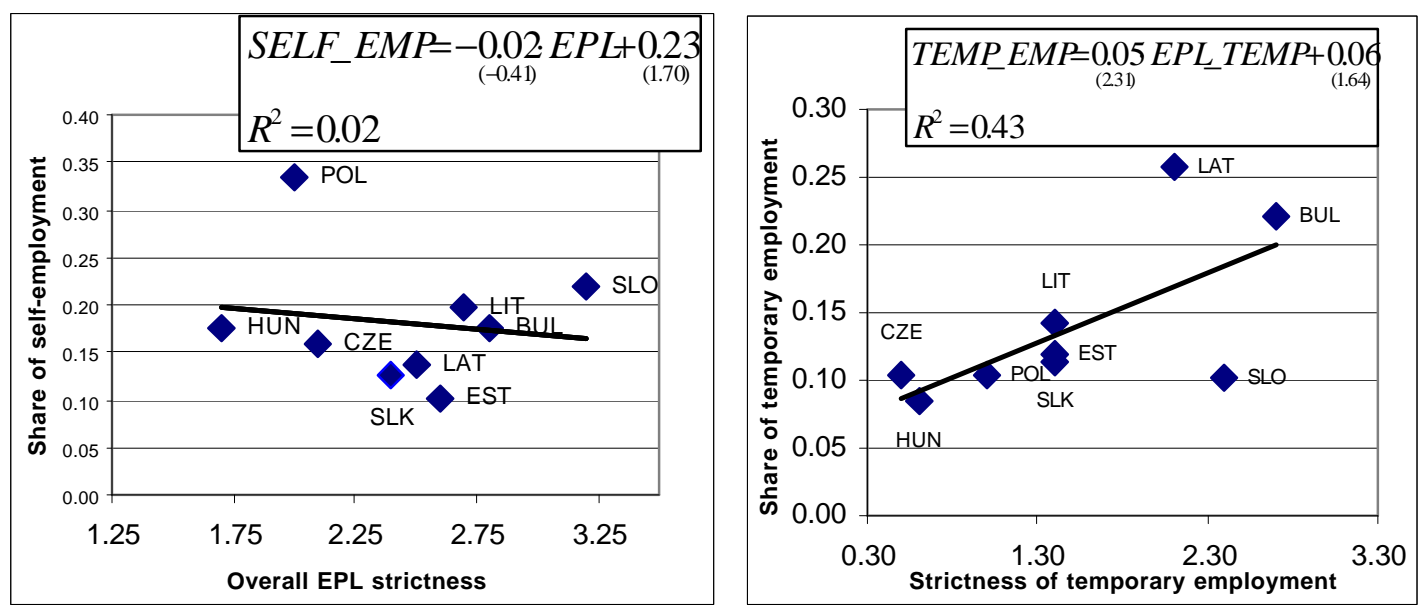

Figure 1 Employment shares by type of employment and EPL strictness in CEE countries

Secondly, Appendix 4 shows that the share of employment with regular (unlimited-term) contracts is highest in Estonia (76\% of employment), followed by Lithuania (63\%) and Latvia (55\%). The unweighted average (65\%) is close to EU average $(68 \%)$. As the share of regular employment determines, which proportion of the workforce enjoys protection against dismissals, Bertola et al. (1999) presented another EPL index where the OECD EPL strictness index is multiplied by the coverage ratio (share of regular employment). The values in Appendix 4 show that as far as Baltic States are concerned, the results are a bit different, the value of index is highest in Estonia (2.3), followed by Lithuania (1.9) and Latvia (1.3). The averages of Baltic States and EU countries are still similar.

Thirdly, though theoretically overall EPL strictness should increase the share of temporary employment, that has not been found empirically, e.g. among OECD countries the relationship was statistically insignificant (OECD 1999). Among the Baltic States, the share of temporary work (respectively $20 \%$ of employment in Latvia, $14 \%$ in Lithuania and $11 \%$ in Estonia) is in all countries above the EU average (10\%). It is surprising for Latvia due to relatively strict regulation of temporary contracts there. For Latvia, a very high share of workers on temporary work agency employment is remarkable $(5.7 \%$, three times the EU average). Somewhat puzzling is the positive relationship between the share of temporary employment and the rigour of respective legislation in the CEE countries (see Figure 1 ). We may ponder whether this surprising finding reflects the poor enforcement of legislation in some of the CEE countries, in particularly Latvia and Bulgaria, where the share of temporary

\footnotetext{
${ }^{8}$ It is important to notice that Baltic States are not homogeneous in respect to self-employment. In Lithuania the share of self-employment in total employment is $19 \%$ (due to high agricultural employment) while in Estonian it is only $10 \%$
} 
employment is the highest, while in more advanced countries like Slovenia, Hungary, Poland, Estonia the share is much lower (around $10 \%$ of employment).

Finally we notice that of part-time employment is much less widespread in CEE than EU countries, lowering also the flexibility. There could be different reasons for the low amount of part-time arrangements, e.g. it is impossible to afford any reasonable living standard when working part time due to the low overall low levels of wages, but also employers might prefer to have full-time employees. It seems the latter reasons have become more important over the time. Concerning various reasons for having part-time job, the amount of involuntary part time (i.e. the reason is due to employer or the failure to find full-time job) has grown in Estonia for example from $42 \%$ in 1993 to $51 \%$ in 2002.

The evidence in this section may suggest some ways for improving flexibility in labour markets. In particular, while the regulations on temporary work agency employment are often absent, the share of temporary work agency employment is not always significantly larger than in EU countries on average. The above analysis has been based only on a data ane point of time. However, also the data on four countries (Estonia, Czech Republic, Poland, Slovenia) presented by Casez and Nesporova (2001) did not reveal any increase in temporary employment and tendency to more flexible forms of employment.

The frequency of different types of employment is actually just one of measures of the coverage of employment security laws. Dasgupta (2001) argued that other relevant features are proportion of workforce in particular sectors, work status, age groups, size of establishments covered by these laws, the percentage of people covered by collective agreements and rate of unionisation. Unions could supervise how labour relations comply with the legal provisions and help its members' interest in case of disputes. For Latvia it s important to note that according to labour code valid till 2002 it was not allowed to dismiss the employee without the consent of the trade union. The rate of unionisation and the coverage of collective bargaining both are rather low in the Baltic States compared with average of EU member states (Table 2). Low unionisation is also one feature of high labour market flexibility in the Baltic States.

\subsection{Employer's estimates of EPL strictness}

Further information on labour market flexibility that considers, at least to some extent, also the actual enforcement of legal provisions, comes from inquiries among employers. We argue that managers consider not only the strictness of laws, but also the extent to which law 
enforcement agencies (e.g. courts) execute these laws, e.g. how often employees' complaints for unfair dismissals are uphold in courts of law. We present here the data from the World Competitiveness Yearbook 2001 that is based on the Executive Opinion Survey carried out by the International Institute for Management Development among 3678 business executives in senior and middle management around the world. For more information on the survey design and the methodology see World Competitiveness Yearbook 2001.
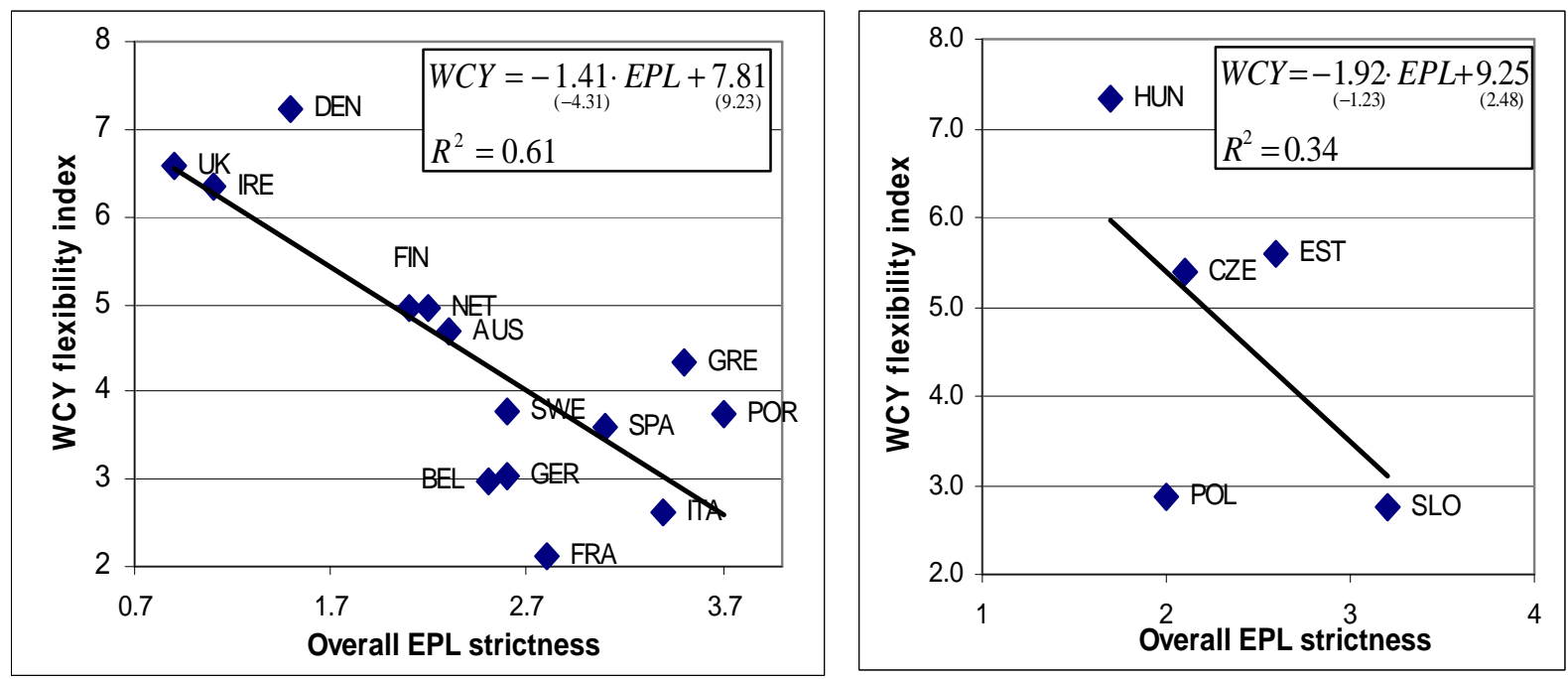

Figure 2 The relationship between the OECD overall EPL strictness index and World Competitiveness Yearbook labour legislation flexibility index (Left panel: sample of EU member countries; right panel: sample of 5 CEE countries.

Source: author's calculations; The World Competitiveness Yearbook 2001; OECD 1999; Riboud et al. 2002; Cazes 2002)

Note. The WCY flexibility index has values from 0 (low flexibility) to 10 (high flexibility, i.e. low strictness) and has been obtained through a survey of top and middle management executives. The total number of respondents was in 20013678 in the world.

Figure 2 examines the relationship between the OECD and WCY indexes of labour regulations. The latter is showing whether "Labour regulations (hiring and firing practices, minimum wages, etc.) are not flexible enough/are flexible enough" on a 0-10 scale. The negative correlation between the two indexes is because one of them (OECD index) measures the strictness and the other one (WCY) flexibility of regulations. Though there is statistically significant correlation between the two indexes, a significant portion of the variation in the WCY index is unexplained by the OECD index, possibly due to factors like the degree of law enforcement. For the small sample of CEE countries the relation seems to be even weaker and the variation in WCY index compared to the variation in the OECD index is bigger in CEE countries than in EU countries (poorer law enforcement?). So we argue that this index gives additional and independent information compared with those calculated in section 4 . On the other hand, the WCY index could also due to the relatively small numbers of responses in individual countries (on average 70-75 per economy, for small countries presumably even 
less) and contain also variation because of factors other than firing and hiring regulations (minimum wages).

The average index value is little higher for CEE countries than for the EU (4.8 and 4.4. respectively). The only Baltic State in the sample, Estonia, with its value ranked among CEE countries similarly to when using OECD EPL index. Though OECD legislation index shows slightly stricter legislation in Estonia compared to EU, business executives estimate the labour regulations to be more flexible in Estonia than in the EU. Even more striking differences between two indexes can be seen for Russia, where OECD index showed rather strict regulations (index value 3.2 compared to EU average of 2.5), but WCY index refers to the rather high level of flexibility (ranks $15^{\text {th }}$ in the sample of 49 countries), which may indicate rather poor law enforcement. For instance, Denisova, Friebel and Sadonikova (1998) report that $50 \%$ of labour disputes related to unfair dismissals is not concluded within the deadline stipulated by the law. The evidence may suggest that that labour markets are more flexible than one might have thought when considering only applicable formal legislation.

Table 5 Correlations between various labour regulations indexes and legal structure indexes in EU countries (upper figures) and CEE transition countries (lower figures)

\begin{tabular}{|c|c|c|c|c|c|c|c|c|}
\hline & $\begin{array}{l}\text { OECD } \\
\text { EPL } \\
\text { index }\end{array}$ & $\begin{array}{l}\text { Law and } \\
\text { order } \\
\text { index }\end{array}$ & $\begin{array}{l}\text { Legal } \\
\text { System \& } \\
\text { Property } \\
\text { Rights }\end{array}$ & $\begin{array}{l}\text { Impact of } \\
\text { minimum } \\
\text { wage }\end{array}$ & $\begin{array}{l}\text { Hiring and } \\
\text { firing } \\
\text { practices }\end{array}$ & $\begin{array}{l}\text { Collective } \\
\text { bargaining } \\
\text { coverage }\end{array}$ & $\begin{array}{l}\text { Unemployment } \\
\text { insurance }\end{array}$ & $\begin{array}{l}\text { Labor } \\
\text { ttmarket } \\
\text { regulations }\end{array}$ \\
\hline \multirow[b]{2}{*}{ OECD EPL index } & 1.00 & $0 \quad-0.61$ & $1 \quad-0.73$ & -0.57 & $\begin{array}{l}7 \\
-0.65\end{array}$ & -0.26 & -0.03 & $\begin{array}{ll}3 & -0.53 \\
\end{array}$ \\
\hline & 1.00 & 0.21 & -0.15 & -0.54 & -0.07 & -0.04 & 0.32 & -0.59 \\
\hline \multirow{2}{*}{$\begin{array}{l}\text { Law and Order } \\
\text { index }\end{array}$} & & 1.00 & 0.85 & 0.50 & 0.28 & -0.01 & -0.19 & 0.14 \\
\hline & & 1.00 & 0.79 & 0.32 & -0.76 & -0.39 & 0.20 & -0.42 \\
\hline \multirow{2}{*}{$\begin{array}{l}\text { Legal System \& } \\
\text { property rights }\end{array}$} & & & 1.00 & 0.56 & 0.36 & -0.04 & -0.38 & 0.17 \\
\hline & & & 1.00 & 0.73 & -0.59 & -0.55 & -0.22 & -0.15 \\
\hline \multirow{2}{*}{$\begin{array}{l}\text { Impact of } \\
\text { minimum wage }\end{array}$} & & & & 1.00 & 0.15 & -0.09 & -0.43 & 0.01 \\
\hline & & & & 1.00 & -0.13 & -0.69 & -0.24 & 0.16 \\
\hline \multirow{2}{*}{$\begin{array}{l}\text { Hiring and firing } \\
\text { practices }\end{array}$} & & & & & 1.00 & 0.41 & 0.26 & 0.51 \\
\hline & & & & & 1.00 & 0.51 & 0.31 & 0.74 \\
\hline $\begin{array}{l}\text { Collective } \\
\text { bargaining } \\
\text { coverage }\end{array}$ & & & & & & 1.00 & 0.48 & $\begin{array}{l}0.78 \\
0.44\end{array}$ \\
\hline \multirow{2}{*}{$\begin{array}{l}\text { Unemployment } \\
\text { insurance }\end{array}$} & & & & & & & $\begin{array}{l}0.50 \\
1.00\end{array}$ & \begin{tabular}{|c|c|}
0.40 \\
\end{tabular} \\
\hline & & & & & & & 1.00 & 0.55 \\
\hline $\begin{array}{l}\text { Labour market } \\
\text { regulations }\end{array}$ & & & & & & & & $\begin{array}{l}1.00 \\
1.00\end{array}$ \\
\hline
\end{tabular}

Source: authors' calculations; Gwartney et al. 2002.

Another information on employer opinions is from Fraser Institute (Gwartney et al. 2002) that supplies a comprehensive dataset on different dimensions of economic freedom, including also indices of labour market regulations and legal structure. The correlations between different indicators are Table 5. It is interesting that the law and order sub-index is negatively related with the index on hiring and firing practices being set by private contracts (labour 
flexibility index) for $8 \mathrm{CEE}$ countries (the value of correlation coefficient is 0.76 ), while the relationship is much weaker for 14 EU member countries (correlation coefficient 0.28). Further, the OECD EPL index shows negative correlation (-0.64) with hiring and firing practices for EU countries, but not in the transition countries (correlation coefficient is only 0.07). This is to say that for transition countries the estimated strictness or flexibility need not to be determined insomuch by formal legislation but also by enforcement, degree of violations et cetera.

\subsection{Violations of labor laws and labor disputes}

Though the existing papers on labour flexibility in CEE countries have focused only on the strictness of applicable formal legislation, it is vital to extend the analyses to the enforcement procedures (court practice) as there is a lot of evidence on the violation of the regulations on employment relationships. Due to the focus of the paper, only violations of labour legislation are reviewed and violations of labour protection legislation are left aside. The data on the violations discovered by national labour inspections (see Table 6) indeed shows that, in a very high proportion of enterprises, laws regulating labour relations are sometimes violated. Surveys of employees have yielded similar results: in a study in Latvia only $8.7 \%$ of employees said that the situation in the area of protection of labour rights is at least quite good and very many complained about different violations of labour laws (Social Report 2001). These issues may be relevant for other CEE countries as well, e.g. in another study in Hungary $85 \%$ of private respondents reported they had no serious constraints in dismissing workers (Kuddo 1995). Though we do not have data by enterprise size, employment protection regulations might be less enforced for small firms: Cazes and Nesporova (2001) showed that employees in larger establishments in transition economies have significantly longer job tenure in comparison to employees in smaller establishments. It means, that while in Western Countries flexibility is attained by using flexible employment contracts (temporary contracts, temporary work agency employment etc.), in transition countries employers often attain flexibility simply just by not following the regulations. 
Table 6 Violations of labour laws in the firms of Baltic States

\begin{tabular}{|c|c|c|c|c|}
\hline & $\begin{array}{l}\text { Checked } \\
\text { enterprises }\end{array}$ & $\begin{array}{l}\text { Checked } \\
\text { enterprises as } \\
\% \text { of total } \\
\text { number of } \\
\text { enterprises }\end{array}$ & $\begin{array}{l}\text { Number of } \\
\text { violations pe } \\
\text { enterprise }\end{array}$ & $\begin{array}{l}\text { Percent of } \\
\text { firms where } \\
\text { labour } \\
\text { rrelations are } \\
\text { violated }\end{array}$ \\
\hline Latvia & 10086 & $3 \quad 37 \%$ & 1.4 & n.a. \\
\hline Lithuania & 12184 & $18 \%$ & n.a. & $61 \%$ \\
\hline Estonia & 1926 & $7 \%$ & 0.5 & $46 \%$ \\
\hline
\end{tabular}

Source: Tööinspektsioon (www.ti.ee), Lietuvos Respublikos Valstybine darbo inspekcija (www.vdi.lt), Latvian State Labour Inspectorate (www.vdi.lt).

Important evidence in all surveys (WLB, NORBALT, $\mathrm{LFS}^{9}$ ) is that significant percentage of workers had no written labour agreement, i.e. the conditions had been agreed orally. In WLB, it was $11 \%$ in 1998 and $5 \%$ in 2002. The LFS and NORBALT surveys indicate the presence of oral agreements to be somewhat lower, respectively ca $3-4 \%$ and $4 \%$. When thinking about these numbers, we should remember that such practices are against the law. ${ }^{10}$ Such practices vary across enterprises and regions. In 1999 almost every fifth of the persons working in Estonian enterprises had not signed a written contract (Antila, Ylöstalo 2002). In the regional dimensions, the results are somewhat controversial. According to WLB survey, the lack of any written contract is most frequent in Tallinn (14 and $7 \%$ in 1999 and 2001). ELFS data shows that oral agreements are twice as frequent in rural than in urban areas. This latter evidence is perhaps a bit more plausible at least in the Estonian case.

There are some differences in the settlement of labour disputes across Baltic Countries. In Estonia the disputes may be settled by either labour dispute committees established within the local labour inspectorates or by the courts. The former are made up of the representatives of both employees and employers and are the first step in the settlement procedure. Similarly in Lithuania labour disputes may be heard by the courts or commission for labour disputes found within enterprises and consisting of employee and employer representatives. In Latvia according to the Labour Code valid till 2002, labour disputes were tried either by courts or labour dispute commissions, the latter being the compulsory first step in the process (except those disputes which in accordance with the law were tried directly by the court) and elected

\footnotetext{
9 The information originates from the following surveys: Estonian Labour Force Survey (hereafter LFS) 19892003 by the Statistical Office of Estonia; Living Conditions Study in Estonia (part of the survey NORBALT I and II. Living Conditions in the Baltic Countries) for 1994 and 1999 by the Norwegian Research Council; Working Life Barometer in the Baltic Countries 2002 and 1999 by the Finnish Ministry of Labour; First candidate countries survey for the working conditions 2001 (by the European Foundation for the Improvement of Working and Living Conditions).

10. For instance in Estonia according to the Estonian Law of Employment Contract (paragraph 28)) labour contract should be concluded in written form.
} 
by the employers and the employees. The new Latvian labour law valid since 2002 no longer mentions labour dispute commissions ${ }^{11}$.

Bertola et al. (1999) have noticed that measuring the enforcement of EPL is difficult as statistical information is relatively scarce, it is seriously affected by selection bias and jurisprudence may be affected by the underlying labor market conditions, i.e. become endogenous (e.g. court rules may become favorable to employees in case of heavy labor market conditions). Having these caveats in mind, we may infer from the information presented in table below that in Baltic States employees have been rather active in submitting complaints to labor inspectors, and they have won quite a high percentage of cases (compared with the average numbers of EU countries); still the latter may be induced by the frequent violations in the first place. The much lower number of cases in courts is because commissions are the first step in dispute resolution. Also the limited court capacity may be the problem. For Latvia it has been mentioned that labor dispute resolution with the assistance of labor dispute commissions or courts is not widespread (Social Report 2001). Though Bertola et al. (2002) found that countries where high number of cases in tribunals was associated with a high percentage of cases favorable to employees, we can't see that when comparing 3 Baltic States. The definition of unfair dismissal (column 5) may both encourage workers to appeal and encourage employers to reach agreements before appeal, so it hard to say whether that is behind the high rate of appeals in Baltic States. In conclusion our finding is that concerning the available scarce evidence on the enforcement of EPL, in Baltic States compared to EU the enforcement indicators are at a relatively higher level that however is also due to the frequent violation of regulations.

Table 7 The enforcement of EPL in Baltic States and EU countries

\begin{tabular}{|lcccc|}
\hline & Year & $\begin{array}{c}\text { Complaints to } \\
\text { inspection } \\
\text { (tribunals) } \\
\text { /employees (\%) }\end{array}$ & $\begin{array}{c}\text { \% of cases } \\
\text { won by } \\
\text { workers }\end{array}$ & $\begin{array}{c}\text { Strictness of unfair } \\
\text { dismissal definitions, } \\
\text { scale 0 to 3 }\end{array}$ \\
\hline Latvia & 2000 & $0.19 \%$ & $88 \%$ & 2 \\
Lithuania & 2000 & $0.22 \%$ & $68 \%$ & 1 \\
Estonia & 2000 & $0.54 \%$ & $65 \%$ & 2 \\
Baltic & 2000 & $0.32 \%$ & $73 \%$ & 1.7 \\
EU & 1995 & $0.21 \%$ & $50 \%$ & 0.9 \\
US & 1995 & $0.02 \%$ & $48 \%$ & 0 \\
\hline
\end{tabular}

Source: Authors calculations; Bertola, Boeri, Cazes 1999. Tööinspektsioon (www.ti.ee), Lietuvos Respublikos Valstybine darbo inspekcija (www.vdi.lt), Latvian State Labour Inspectorate (www.vdi.lt $)$. OECD (1999): scored 0 - worker capability or redundancy of the job are adequate grounds for dismissal, 1 when social considerations, age or job tenure must when possible influence the choice of which worker(s) to dismiss; 2 when a transfer

\footnotetext{
${ }^{11}$ The ability to make appeals to courts or commissions is subject to deadlines: in Lithuania 1 (according to the new Labour Code - 3), in Latvia one month and in Estonia 4 months.
} 
and/or retraining to adapt the worker to different work must be attempted prior dismissal, and 3 when worker capability cannot be a ground for dismissal.

\section{Interactions of EPL with labour market performance and labour policy}

Finally, we review the existing evidence on the effect of EPL strictness on labour market performance and other institutions in CEE countries. The impact of firing costs on employment and labour market flows has been analysed in a number of studies, and though stricter EPL has been blamed e.g. for the poor performance labour markets in Europe compared USA. Generally the studies have showed that more stringent employment protection has an ambiguous effect on the general level of employment or unemployment, but it reduces labour flows and labour turnover with tenures in both jobs and unemployment lasting longer (Gregg and Manning 1997; Revenga and Bentolila 1995; Jackman et al. 1996; OECD 1999; Bentolila and Saint Paul 1992). In the light of this it is not surprising that Cazes (2002) found the effect of EPL strictness on unemployment rate in the group of 8 CEE countries to be of a very small and statistically insignificant size.

OECD has attempted to link the degree to which countries have followed their prescriptions for labor market deregulation with the extent to which structural unemployment (the NAIRU)has declined (see for example, OECD 1999). Baker et al (2002) constructed from OECD sources an index of the extent of labor market deregulation in the 1990s and showed that there is no meaningful relationship between labor market deregulation and shifts in the NAIRU. It is also worth noting that a leading paper by OECD economists found that nearly all of the change in structural unemployment rates between 1990 and 1995 was accounted for by country-specific effects, not by "institutional factors" (Elmeskov et al, 1998, Table 3 and page 11).

Blanchard and Wolfers (2000) hold that their results provide support for the view that the combination of macroeconomic shocks from the 1960s to the 1990s with the rigidity in the labor markets in some countries helps to explain both the general increase in the unemployment over the last three decades and the variation across countries. They conclude by noting that institutions are becoming more "employment-friendly," and that "further improvements should help reduce unemployment - although the poor results obtained using time-varying institutions make us reluctant to push this position strongly, at least based on the evidence in this paper" (p 19).

\footnotetext{
${ }^{12}$ Sources of data: Nesporova 2003; Eurostat; Cazes, Nesporova 2001.
} 
Analysing the effects of EPL on labour market performance, we start from wage setting. If the employer can freely adjust wages, they may push wages down below the employee's reservation wage in order to induce voluntary leave, that may undo the economic effects of employment protection legislation. As a second example, empirical data (e.g. for EU countries presented in Boeri et al. 2002) has indicated the presence of trade-off between the coverage of unemployed people with unemployment insurance system, and the strictness of overall EPL as measured by the OECD index. Indeed, both EPL and unemployment insurance are designed for a similar purpose, i.e. to protect individuals against uninsurable unemployment risk. Protection from job loss is all the more desirable if unemployment insurance coverage is low, and conversely, weak job security makes extensive unemployment insurance more desirable. The figure confirms that this policy trade-off can be identified in the sample of nine CEE countries. We should note by unemployment insurance coverage that registered and labour force survey based unemployment rates are for some countries (e.g. Baltic States) significantly different.

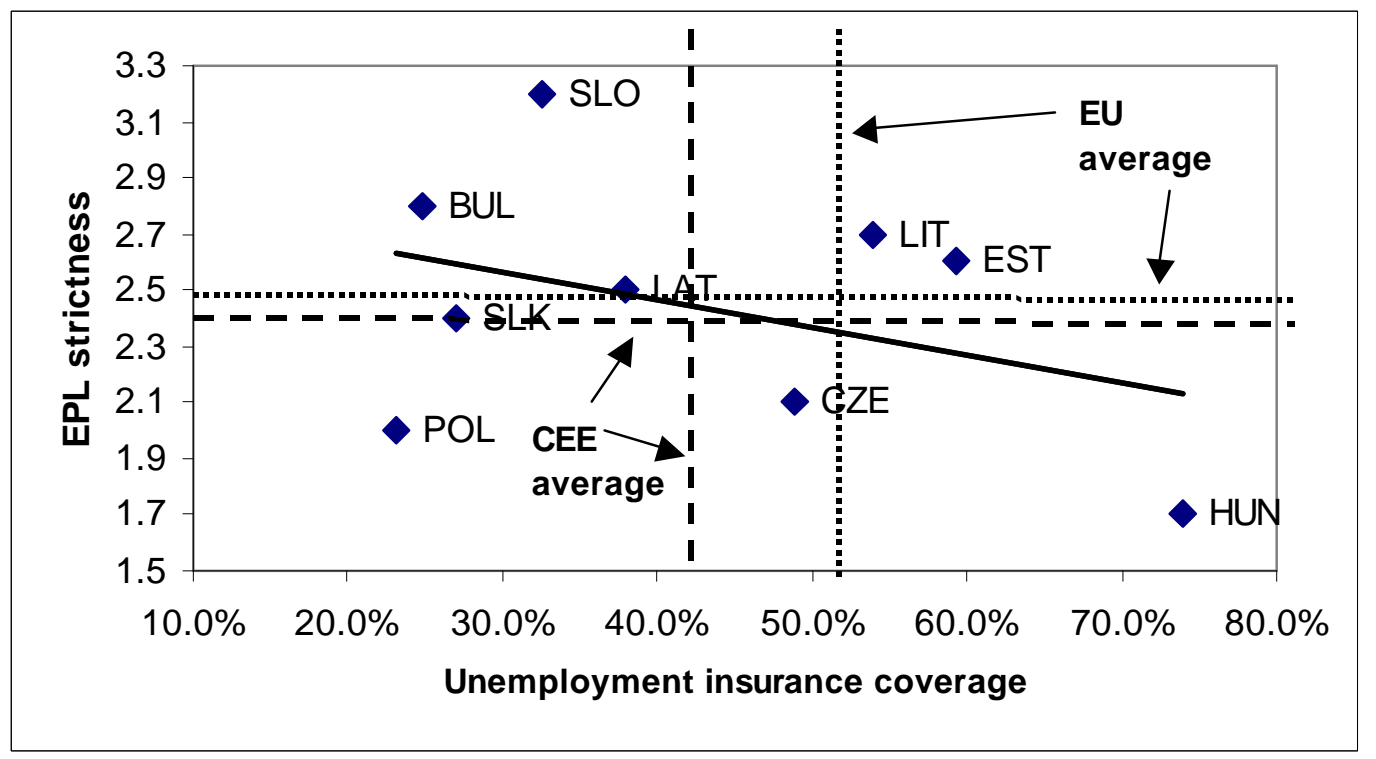

Figure 3 Trade-off between unemployment insurance coverage and overall EPL strictness in CEE countries (late 90's) 
Table 8 The overall protection index (unemployment benefits and EPL strictness)

\begin{tabular}{|lccccccc|}
\hline & $\begin{array}{c}\text { Benefit re- } \\
\text { placement } \\
\text { rate }\end{array}$ & $\begin{array}{c}\text { Unemploy- } \\
\text { ment insur- } \\
\text { ance cover- } \\
\text { age rate }\end{array}$ & $(1) \times(2)$ & $\begin{array}{c}\text { Scaled un- } \\
\text { employment } \\
\text { insurance } \\
\text { index }\end{array}$ & $\begin{array}{c}\text { Overall } \\
\text { EPL } \\
\text { strictness }\end{array}$ & $\begin{array}{c}\text { Scaled } \\
\text { EPL index }\end{array}$ & $\begin{array}{c}\text { Protection in- } \\
\text { dex }\end{array}$ \\
\hline & $(1)$ & $(2)$ & $(3)$ & $(4)$ & $(5)$ & $(6)$ & 2 \\
\hline Latvia & $25.0 \%$ & $37.9 \%$ & $9.5 \%$ & 2.1 & 2.5 & 7.4 & 4.8 \\
Lithuania & $17.0 \%$ & $53.9 \%$ & $9.2 \%$ & 2.0 & 2.7 & 8.0 & 5.0 \\
Estonia & $7.0 \%$ & $59.3 \%$ & $4.2 \%$ & 0.9 & 2.6 & 7.7 & 4.3 \\
CEE average & $44.1 \%$ & $42.4 \%$ & $17.9 \%$ & 4.0 & 2.4 & 7.3 & 5.6 \\
EU & $49.8 \%$ & $53.0 \%$ & $26.4 \%$ & 5.9 & 2.5 & 7.4 & 6.7 \\
USA & $16.0 \%$ & $15.0 \%$ & $2.4 \%$ & 0.5 & 0.7 & 2.1 & 1.3 \\
\hline
\end{tabular}

Source. Authors' calculations; Boeri et al. 2002; Paas et al. 2003; Cazes 2002.

Note. The scaled index is obtained by assigning 10 to the numerical value corresponding to the average value of the index plus two standard deviations.

Boeri et al. (2002) in their paper aggregated the information on two measures targeted at insurance against unemployment, EPL and unemployment benefits, into an unemployment protection index for the EU countries. Here we do analogous calculations for the sample of The Baltic States and other CEE countries.

Table 8 includes in the first two columns benefit replacement rates and percentage of unemployed people covered by unemployment insurance. In the third column unemployment insurance index is calculated as the multiple of the two numbers. The protection index is a simple average of scaled unemployment insurance and EPL indices. In the Baltic States the index is largest for Lithuania and smallest for Estonia, still, in comparison with EU countries, the protection is relatively low, i.e. EPL does not balance the low unemployment insurance coverage in CEE coverage.

\section{Conclusions}

The aim of this paper was to estimate the strictness of employment protection and enforcement of legal provisions in the Baltic States. The EPL forms together with trade unions and labour market policies one component of the institutional labour market flexibility, and it affects also the micro level flexibility by lowering turnover in the labour market with both jobs and unemployment spells tending to last longer.

The Baltic States have followed main international labour standards as well as adopted most of the EU directives on labour relations and the overall strictness of labour regulations is close to the EU level. However, there exist also cross-country differences. Individual dismissals are less unconstrained in Latvia compared to Estonia and Lithuania; the value of the index for the 
Baltic States is higher than the average of the European Union. On the other hand, the use of temporary employment is less restricted in the Baltic States than in the EU; Latvia their use is less restricted than in Lithuania and Estonia. Among the group of CEE countries the crosscountry variation is greatest in this area. In all three Baltic Countries the regulation of collective dismissals is stricter than in the EU countries on the average (that actually characterizes the whole set of CEE countries). Despite the differences in most of the detailed indicators, the overall EPL strictness seems to be not very different across the Baltic States (in Latvia the regulation is possibly more favorable to employers). Compared with other Central and Eastern European Countries (CEEC) the EPL regulation is, in all 3 areas, (individual dismissals, temporary forms of employment, collective dismissals) slightly stricter in the Baltic States and despite some differences they seem to constitute a relatively homogenous group.

From a formal point of view the legal regulation of the labour market seems to be in place and the worker is even better protected in the Baltic States than in EU. But in practice, it appears that state regulations are not always followed in the private sector. As we saw, there is a lot evidence of violations of these regulations in enterprises in the Baltic States. Workers complaints to labour inspectors are rather frequent and in labour disputes employees' appeals are rather often followed, which may indicate that law enforcement is not that weak. But the problem is that appeals may constitute only a small number of all law breaks. There are other reasons to believe that the number of unreported violations is even higher, for example in many cases so called voluntary leaves are only reported as voluntary. There are evidences of existence of so call extra agreements (such a contract could be a notice of dismissal (voluntary leave) signed by employee and left with the employer with open date). In other words the employee and employer could sign an extra agreement by which employee resigns some of his/her benefits for the employers benefit.

Secondly, it is important for EPL strictness, which proportion of the workforce is actually covered by the regulations. In the Baltic States we found that the share of workers on unlimited contracts is close to the EU level, but temporary employment is more widespread (implying a higher level of flexibility). The positive correlation between the share of temporary employment and the strictness of respective legislation in CEE countries may reflect the poor enforcement of legislation in some CEE countries. The latter may also be the reason why the employers' evaluations of the flexibility of labour legislation rather imperfectly reflect the strictness of formal legislation. 
The existing evidence of EPL on actual labour market performance does not show that stricter EPL results in higher unemployment in the CEE countries, but as we have argued, it is hard to measure the actual EPL strictness. When estimating the effect of EPL on labour market performance, it is to be borne in mind that EPL does not work in isolation from other institutional structures of the labour market. For CEE countries there is clear evidence concerning the policy trade-off between two measures of insurance against unemployment, EPL and unemployment insurance. In any case, the overall level of protection aggregating both measures of insurance against unemployment is rather low compared to that of EU countries.

The power of institutions will increase because the control over these regulations will increase, caused by increasing administrative capacity. So it is likely that labour markets in the Baltic States will become more rigid. Still, when considering possible policy implication, we find it important to repeat the statement of Bertola et al .(2000, p.99) who said that these "should not be based on any of the indicators available to date" as these "are too imperfect and imprecise to inform the debate on EPL reforms and cannot be attached a normative content when monitoring structural reforms in the labour markets". 


\section{References}

Addison, J. T. and T. Paulino (2001), "The Economics of Employment Protection", IZA Discussion Paper, No. 381, 63 pp.

Aghion, P. and O. Blanchard (1994), "On the speed of transition in Central Europe". National Bureau for Economic Research Macroeconomic Annual, pp. 283-320.

Antila, J. and P. Ylöstalo, P (2002), "Working Life Barometer in the Baltic Countries". Helsinki, Ministry of Labour, Labour Policy Studies No. 247, 327 pp.

Avaliku teenistuse seadus. Public Service Act. (01.01.1996). [http://lex.andmevara.ee/estlex/index.jsp]

Baker, D., Howell, D. Glyn, A. and Schmitt, J., (2002), "Labor Market Institutions and Unemployment: A Critical Assessment of the Cross-Country Evidence", CEPA Working Paper 2002-17, November 8.http://www.newschool.edu/cepa/papers/archive/cepa200217.pdf

Ball, L. (1996), "Disinflation and the NAIRU", National Bureau of Economic Research, Working Paper No. 5520.

Belot, M. and J. van Ours (2000), "Does the recent success of some OECD countries in lowering their unemployment rates lie in the clever design of their labour market reforms?", IZA Discussion Paper No 147, 49 pp.

Bentolila, S. and G. Saint Paul (1992). "The Macroeconomic Impact of Flexible Labour Contract, with an Application to Spain", European Economic Review, Vol. 36, No. 5.

Berthold, N. and R. Fehn (1996), "The Positive Economics of Unemployment and Labour Market Flexibility", KYKLOS, Vol 49, Fasc. 4, pp. 583-613

Bertola, G. (1990), "Job security, employment and wages", European Economic Review, Vol. 34, pp. 851-879.

Bertola, G., Boeri, T. and S. Cazes (1999), "Employment protection and labour market adjustment in OECD countries: Evolving Institutions and variable enforcement", ILO, Employment and training papers 48, 103 pp.

Bertola, G., Boeri, T., and S. Cazes (2000), "Employment protection regulation in industrialized countries: The case for new indicators", International Labour Review, 2000/1, $12 \mathrm{pp}$.

Betcherman, G., Luinstra, A. and M. Ogawa (2001), "Labour Market Regulation: International Experience in Promoting Employment and Social protection”, World Bank Social Protection Unit, Social Protection Discussion Paper No 0128, 65 pp.

Blanchard, O. and J. F. Jimeno (1995), "Structural unemployment: Spain versus Portugal", American Economic Review Papers and Proceedings, 85(2), pp. 212-218.

Blanchard, O. and J. Wolfers (2000), "The Role of Shocks and Institutions in the Rise of European Unemployment: the Aggregate Evidence.", The Economic Journal 110 (March): C1-C33.

Boeri, T. (2000). Structural Change, Welfare Systems and Labour reallocation: Lessons from the Transition of formerly Planned Economies. Oxford, Oxford University Press

Boeri, T. and H. Brücker (2001), "Eastern Enlargement and EU-Labour Markets: Perceptions, Challenges and Opportunities", IZA Discussion Paper No 256.

Boeri, T., Garibaldi, P., Macis, M. and M. Maggioni (2002). Adaptability of labour markets: a tentative definition and a synthetic indicator. Fondazione Rodolfo Debenedetti, Milan, June 2002. 
Boyer, R. (ed.)., (1988). The search for labour market flexibility. The European economies in transition. Oxford, Claredon Press.

Brücker, H. and T. Boeri (2000). The Impact of Eastern Enlargement on Employment. Berlin, Milano, European Integration Consortium.

Burda, M. (1998), "The consequences of EU enlargement for Central and Eastern European labour markets", in Employment in Europe, European Central Bank, pp. 65-82

Carley, M. (2002), "Industrial relations in the EU Member States and Candidate Countries." European Industrial Relations Observatory, European Foundation for the Improvement of Working and Living Conditions.

http://www.eiro.eurofound.ie/2002/07/Feature/TN0207104F.html

Cazes, S. (2002), "Do labour market institutions matter in transition economies? An analysis of labour market flexibility in the late nineties", International Institute for Labour Studies Discussion Paper 140/2002, 33 pp.

Cazes, S. and A. Nesporova (2001), "Job insecurity in transition economies: how much is too much", International Labour Review, Vol. 140, No. 3., 293-325.

Dasgupta, S., (2001). Employment Security: Conceptual and Statistical Issues. International Labour Office, Geneva.

Denisova, I., Friebel, G. and E. Sadovnikova (1998), "Internal Labour Markets and Human Resource Policies: an Account from the Existing Surveys", RECEP Working Paper No.6., 1998

Dore, R. (1986). Flexible rigidities: Industrial policy and structural adjustment in the Japanese economy 1970-80. London, Athlone Press.

Eamets, R (2004) Labour Market Flows and Adjustment to Macroeconomic Shocks in the Baltic States, Post-Communist Economies, Vol 16, No1, March, pp 47-71

Elmeskov, J., Martin J. and S. Scarpetta (1998), "Key Lessons for Labor Market Reforms: Evidence from OECD Countries Experience." Swedish Economic Policy Review 5(2), pp. 205-252

Employment in Europe, 1996. (Luxemburg, European Commission). European Economy, Statistical Appendix No. 62.

Employment Protection Regulations: Rules for Hiring and Terminations, 2002. World Bank. www.worldbank.org

European Foundation for the Improvement of Living and Working Condition, 2001. First candidate countries survey on working conditions.

http://www.eurofound.eu.int/working/ccindex.htm

Freeman, R.B. (1993), "Labor Market Institutions and Policies: Help or Hindrance to Economic Adjustment?" Proceedings of the World Bank Annual Conference on Development Economics, 1992. Supplement to the World Bank Economic Review and the World Bank Research Observer.

Gregg, P. and A. Manning (1997), "Labour market regulation and unemployment", in: D.J. Snower and G. de la Dehesa (Eds.) Unemployment Policy, pp. 395-424 (Cambridge, Cambridge University Press).

Grubb, D. and W. Wells (1993), "Employment Regulation and Patterns of Work in EC Countries", OECD Economic Studies, no. 21, pp. 7-58.

Gwartney, J. and Robert L., with W. Park, S. Wagh, C. Edwards, and V. de Rugy (2002) Economic Freedom of the World: 2002 Annual Report. Vancouver: The Fraser Institute, 2002. 
Data retrieved from www.freetheworld.com

Hahn, F. (1998), "Labour market flexibility and welfare", Quaderni del Dipartimento di Economia Politica No. 223, Universita degli Studi di Siena.

Ichionowski, C., Shaw, K. and Prennushi (1997), "The Effects of Human Resource Management Practices on Productivity”, National Bureau of Economic Research Working Paper No. 5333

Jackman, R. Layard, R. and Nickell S. (1996), "Combating unemployment: is flexibility enough?", in OECD, Macroeconomic Policies and Structural Reform, Paris, pp. 19-49

Kravaritou-Manitakis, Y. (1988). New forms of work: Labour law and social security aspects in the European Community. Dublin, European Foundation for the Improvement of Living and Working Conditions.

Kuddo, A. (1995), Emerging Labour Markets, World Development Studies 2, Helsinki: UNU/WIDER.

Lazear, E. P., (1990), "Job Security Provision and Employment", Quarterly Journal of Economics, Vol. 105, Issue 3, pp. 699-726

Nickell, S. (1997), "Unemployment and Labour Market Rigidities: Europe versus North America", Journal of Economic Perspectives. Vol. 11, No 3, pp.55-74.

Nicoletti, G., Bassanini, A., Ernst, E., Jean, S., Santiago, P. and P. Swaim (2001), "Product and labour markets interaction in OECD countries", OECD Economics department working papers No. 312, 110 pp.

Nicoletti, G., Scarpetta, S., and O. Boylaud (2000), "Summary Indicators of Product Market Regulation with an Extension to Employment Protection Legislation", OECD ECO/WKP No. 220,86 p.

OECD, 1994. The OECD Jobs Study, Evidence and Explanations, Part II, Paris.

OECD, 1999. Employment Outlook. Paris.

Orenstein, M. A. and E. Wilkens (2001), "Central and East European Labor Market Institutions in Comparative Perspective", paper prepared for delivery at the 2001 Annual Meeting of the American Political Science Association, San Francisco, August 30-September 2, 2001 .

Paas, T., Eamets, R., Masso, J. and M. Rõõm (2003), "Labour Market Flexibility and Migration in the Baltic States: Macro Evidences", University of Tartu, Faculty of Economics and Business Administration Working Paper Series, No. 16, 101 pp.

Piore, M., (1986). Labour market flexibility, University of California, Berkeley, CA.

Pissarides, C. A. (2001), “Employment protection”, Labour Economics, Vol. 8, pp. 131-159

Regular Report on Estonia's Progress Towards Accession, 2002. Commission of the European Communities, Brussels, October 2002, 143 pp.

Regular Report on Latvia's Progress Towards Accession, 2002. Commission of the European Communities, Brussels, October 2002, 159 pp.

Regular Report on Lithuanias's Progress Towards Accession, 2002. Commission of the European Communities, Brussels, October 2002, 159 pp.

Republic of Latvia Labour Code (with amendments to 25 October 1994). Latvian National Labour legislation. International Labour Organization Central and Eastern European Team. [http://natlex.ilo.org/txt/E94LVA01.htm]

Republic of Lithuania Law on the Employment Contract (12.06.2001). Seimas of the 
Republic of Lithuania. [http://www3.lrs.lt/n/eng/DPaieska.html

Revenga, A.L. and S. Bentolila (1995), "What affects the employment rate intensity of growth?", Banco de Espana, Servicio de Estudios, No. 9517.

Riboud, M., Sanchez-Paramo, C. and C. Silva-Jauregui (2002), "Does Eurosclerosis Matter? Institutional Reform and Labour Market Performance in Central and Eastern European Countries", - in B. Funck and L. Pizzati (Eds.), Labour, Employment and Social Policies in the EU Enlargement Process. pp 243-311. World Bank, Washington,

Siebert, H., (1997), "Labour Market Rigidities: At the Root of Unemployment in Europe", Journal of Economic Perspectives, Vol. 11, No 3, pp.37-54

Simonazzi, A. and P. Villa (1999), "Flexibility and Growth", International Review of Applied Economics, Vol. 13, Issue 3, pp.281-312

Svejnar, J. (2002), "Labour Market Flexibility in Central and East Europe", William Davidson Institute Working Paper Number 496, 32 pp.

The Republic of Estonia Employment Contracts Act. Eesti Vabariigi Töölepingu seadus. (01.07.1992) [http://lex.andmevara.ee/estlex/index.jsp]

The Republic of Latvia Labour Law (01.06.2002). Translation and Terminology Centre [http://www.ttc.lv/en/default-translations-lr.htm]

The Republic of Latvia State Civil Service Law (01.01.2001) Translation and Terminology Centre [http://www.ttc.lv/en/default-translations-lr.htm]

The Republic of Lithuania Law on Public Service (08.06. 1999).

The World Competitiveness Yearbook 2001 (2001). IMD, Geneva.

Treu, T., (1989), "Introduction: New trends in working time arrangements", in A. Gladstone et al. (Eds.): Current issues in labour relations: An international perspective. Berlin and New York, de Gruyter

Treu, T., (1992), "Labour Flexibility in Europe”, International Labour Review, Geneva; Vol. 131, Iss. 4,5; pp.497-513 


\section{Appendix 1 Detailed indicators of employment protection regulation for Baltic States}

Tabel A1.1: Unlimited contracts.

\begin{tabular}{|c|c|c|c|c|c|c|c|c|c|c|c|c|}
\hline \multirow[b]{2}{*}{ Country } & \multirow{2}{*}{$\begin{array}{l}\text { Proce- } \\
\text { dures, } \\
\text { Scale } 0 \\
\text { to } 3 \\
\end{array}$} & \multirow{2}{*}{$\begin{array}{c}\text { Delay to } \\
\text { start a } \\
\text { notice, } \\
\text { days }\end{array}$} & \multicolumn{3}{|c|}{$\begin{array}{c}\text { Notice period } \\
\text { after }\end{array}$} & \multicolumn{3}{|c|}{ Severance pay after } & \multirow{2}{*}{$\begin{array}{l}\text { r Definition of } \\
\text { unfair dis- } \\
\text { missal }\end{array}$} & \multirow{2}{*}{$\begin{array}{l}\text { Trial pe- } \\
\text { f riod before } \\
\text { eligibility } \\
\text { arises }\end{array}$} & \multirow{2}{*}{$\begin{array}{l}\text { Unfair dis- } \\
\text { missal com- } \\
\text { pensation at } 20 \\
\text { years of tenure }\end{array}$} & \multirow{2}{*}{$\begin{array}{l}\text { Extent } \\
\text { of rein- } \\
0 \text { state- } \\
\text { ment }\end{array}$} \\
\hline & & & $9 \mathrm{~m}$ & $4 \mathrm{y}$ & $20 y$ & $9 \mathrm{~m}$ & $4 \mathrm{y}$ & $20 \mathrm{y}$ & & & & \\
\hline Latvia & 1 & 2 & 1 & 1 & 1 & 1 & 1 & 4 & 2 & 3 & 6 & 3 \\
\hline Latvia $^{1}$ & 3 & 2 & 1 & 1 & 1 & 1 & 1 & 1 & 2 & 3 & 6 & 3 \\
\hline Lithuania & 1 & 2 & 2 & 2 & 4 & 4 & 4 & 6 & 1 & 3 & 12 & 3 \\
\hline Lithuania $^{2}$ & 1 & 1 & 2 & 2 & 2 & 1 & 3 & 6 & 2 & 3 & 12 & 3 \\
\hline Estonia & 2 & 2 & 2 & 2 & 4 & 2 & 2 & 4 & 2 & 4 & 6 & 3 \\
\hline Estonia $^{3}$ & 1 & 1 & 1 & 2 & 4 & 2 & 2 & 4 & 2 & 4 & 6 & 1 \\
\hline Baltic & 1.3 & 2.0 & 1.7 & 1.7 & 3.0 & 2.3 & 2.3 & 4.7 & 1.7 & 3.3 & 8.0 & 3.0 \\
\hline CEEC & 1.5 & 6.3 & 2.1 & 2.5 & 3.2 & 1.3 & 1.6 & 4.0 & 1.3 & 2.6 & 7.6 & 2.6 \\
\hline EU15 & 1.7 & 1.7 & 14.7 & 8.7 & 1.0 & 1.0 & 1.8 & 1.6 & 4.4 & 4.2 & 0.3 & 0.3 \\
\hline
\end{tabular}

Tabel A1.2 Temporary employment

\begin{tabular}{|c|c|c|c|c|c|c|}
\hline \multirow[t]{3}{*}{ Country } & \multicolumn{3}{|c|}{ Fixed-term contracts } & \multicolumn{3}{|c|}{ Temporary work agencies (TWA) } \\
\hline & $\begin{array}{l}\text { Valid } \\
\text { cases other } \\
\text { than usual } \\
\text { objective } \\
\text { reasons }\end{array}$ & $\begin{array}{l}\text { Maximum } \\
\text { number of } \\
\text { successive } \\
\text { contracts }\end{array}$ & $\begin{array}{l}\text { Maximum } \\
\text { cumulated } \\
\text { duration }\end{array}$ & $\begin{array}{lr}\text { Types of } \\
\text { work, for } \\
\text { which TWA } \\
\text { employment } \\
\text { is legal }\end{array}$ & $\begin{array}{l}\text { Restrictions on } \\
\text { number } \\
\text { renewals }\end{array}$ & $\begin{array}{l}\text { Maximum } \\
\text { cumulated duration } \\
\text { of temporary work } \\
\text { contracts }\end{array}$ \\
\hline & Scale $0 \ldots 3$ & Number & Month & Scale 0 to 4 & Yes/No & Months \\
\hline Latvia & 0 & No limit & 24 & 4 & No & No limit \\
\hline Latvia $^{1}$ & 0 & No limit & No limit & 4 & No & No limit \\
\hline Lithuania & 1 & No limit & 60 & 4 & No & No limit \\
\hline Lithuania $^{2}$ & 1 & No limit & 60 & 4 & No & No limit \\
\hline Estonia & 1 & No limit & 60 & 4 & No & No limit \\
\hline Estonia $^{3}$ & 1 & 2 & 31 & 4 & No & No limit \\
\hline Baltic avg & 1 & No limit & 48 & 4 & No & No limit \\
\hline CEEC & 1.5 & $\begin{array}{l}2 \text {; No limit in } \\
7 \text { countries }\end{array}$ & $\begin{array}{l}\text { 48; No limit } \\
\text { in } 3 \\
\text { countries }\end{array}$ & 3.6 & $\begin{array}{c}\text { No in } 7, \text { Yes in } \\
1 \text { country }\end{array}$ & $\begin{array}{l}\text { 2; No limit in } 7 \\
\text { countries }\end{array}$ \\
\hline EU15 & 2.0 & $\begin{array}{l}2.5 \text { No limit } \\
\text { in } 3 \text { countries }\end{array}$ & $\begin{array}{c}23.6 \text { No } \\
\text { limit in } 7 \\
\text { countries }\end{array}$ & 2.8 & $\begin{array}{l}\text { No restrictions } \\
\text { in } 5 \text { countries }\end{array}$ & $\begin{array}{l}\text { 16.3 No limit in } 6 \\
\text { countries }\end{array}$ \\
\hline
\end{tabular}

Tabel A1.3 Regulation of collective dismissals

\begin{tabular}{|c|c|c|c|c|c|}
\hline & $\begin{array}{c}\text { Definition of } \\
\text { collective } \\
\text { dismissals a) }\end{array}$ & $\begin{array}{c}\text { Additional } \\
\text { notification } \\
\text { requirements b) }\end{array}$ & $\begin{array}{l}\text { Additional } \\
\text { delays } \\
\text { involved }^{\text {c) }}\end{array}$ & $\begin{array}{l}\text { Other special } \\
\text { costs to } \\
\text { employers }\end{array}$ & $\begin{array}{l}\text { Overall strictness } \\
\text { relative to individual } \\
\text { dismissals e) }\end{array}$ \\
\hline & Scale $0 \ldots 4$ & Scale $0 \ldots 2$ & Days & $1 / 0$ & \\
\hline Latvia & 4 & 2 & 67.5 & 0 & 4.0 \\
\hline Latvia $^{1}$ & 0 & 0 & 0 & 0 & 0 \\
\hline Lithuania & 3 & 2 & 135 & 1 & 4.9 \\
\hline Lithuania $^{2}$ & 3 & 2 & 60 & 0 & 3 \\
\hline Estonia & 4 & 2 & 45 & 1 & 4.5 \\
\hline Estonia $^{3}$ & 4 & 2 & 45 & 1 & 4.5 \\
\hline Baltic's average & 3.7 & 2.0 & 82.5 & 0.7 & 4.5 \\
\hline CEEC & 3.3 & 1.9 & 66.2 & 0.9 & 4.3 \\
\hline
\end{tabular}

Source: authors' calculations; Nicoletti et al. (1999); OECD (1999); Riboud et al. (2002); The Republic of Estonia Employment Contracts Act (valid since 01.07.1992); The Republic of Latvia Labour Law (valid since 01.01.2001); Republic of Lithuania Law on the Employment Contract (valid since 1991).

1. $\quad$ Based on Labour Code valid since 1972 (with amendments) till 01.01.2002

2. Based on new Labour Code valid since 01.01.2003

3. Based on proposed Labour Code. See http://eoigus.just.ee/ 
Appendix 2 Procedure to construct summary indicators of EPL strictness

(Nicoletti et al. 2000)

\begin{tabular}{|c|c|c|c|c|c|}
\hline \multirow{4}{*}{$\begin{array}{l}\text { Share in aggregate index } \\
\text { Share in factor }\end{array}$} & \multicolumn{5}{|c|}{ Overall measure of EPL strictness } \\
\hline & \multirow{2}{*}{\multicolumn{3}{|c|}{$\begin{array}{c}0.50 \\
\text { Unlimited contracts }\end{array}$}} & \multirow{2}{*}{\multicolumn{2}{|c|}{$\begin{array}{c}0.50 \\
\begin{array}{c}\text { Temporary forms of } \\
\text { employment }\end{array}\end{array}$}} \\
\hline & & & & & \\
\hline & 0.44 & 0.30 & 0.26 & & \\
\hline & $\begin{array}{l}\text { Factor1 } \\
\text { Procedural in- } \\
\text { conveniencies }\end{array}$ & $\begin{array}{l}\text { Factor } 2 \\
\text { Direct } \\
\text { firing } \\
\text { costs } \\
\end{array}$ & $\begin{array}{l}\text { Factor } 3 \\
\text { Notice and } \\
\text { probation } \\
\text { period }\end{array}$ & $\begin{array}{l}\text { Factor } 1 \\
\text { Proce- } \\
\text { dures }\end{array}$ & $\begin{array}{l}\text { Factor } 2 \\
\text { Maximum } \\
\text { duration }\end{array}$ \\
\hline Procedures & 0.30 & 0.02 & 0.02 & & \\
\hline Delay to start a notice & 0.28 & 0.00 & 0.00 & & \\
\hline Notice period & 0.02 & 0.02 & 0.44 & & \\
\hline Severance pay & 0.00 & 0.41 & 0.01 & & \\
\hline Definition of unfair dismissal & 0.25 & 0.01 & 0.05 & & \\
\hline Probation period & 0.01 & 0.06 & 0.40 & & \\
\hline Unfair dismissal compensation & 0.13 & 0.11 & 0.08 & & \\
\hline Extent of reinstatement & 0.02 & 0.37 & 0.00 & & \\
\hline $\begin{array}{l}\text { Fixed term contract: valid cases other } \\
\text { than usual objective }\end{array}$ & & & & 0.24 & 0.06 \\
\hline $\begin{array}{l}\text { Fixed term contract: maximum } \\
\text { number of successive contracts }\end{array}$ & & & & 0.22 & 0.12 \\
\hline $\begin{array}{l}\text { Fixed term contract: Maximum } \\
\text { cumulated duration }\end{array}$ & & & & 0.00 & 0.35 \\
\hline $\begin{array}{l}\text { TWA: Maximum number of } \\
\text { successive contracts }\end{array}$ & & & & 0.24 & 0.10 \\
\hline TWA: Maximum cumulated duration & & & & 0.22 & 0.08 \\
\hline Type of work for which TWA is legal & & & & 0.07 & 0.29 \\
\hline
\end{tabular}


Appendix 3 Four-step procedure to construct summary indicators of EPL strictness (OECD 1999)

\begin{tabular}{|c|c|c|c|c|}
\hline Level 1 & & Level 2 & Level 3 & Level 4 \\
\hline $\begin{array}{l}\text { Procedures }(1 / 2) \\
\text { Delay to start a notic }\end{array}$ & & $\begin{array}{l}\text { Procedural inconveniences } \\
(1 / 3)\end{array}$ & \multirow{3}{*}{$\begin{array}{l}\text { Regular contracts } \\
(5 / 12)\end{array}$} & \multirow{6}{*}{ EPL Overall summary indicator } \\
\hline $\begin{array}{l}\text { Notice period after } \\
\text { Severance pay after }\end{array}$ & $\begin{array}{l}9 \text { months }(1 / 7) \\
4 \text { years }(1 / 7) \\
20 \text { years }(1 / 7) \\
9 \text { months }(1 / 7) \\
4 \text { years }(1 / 7) \\
20 \text { years }(1 / 7)\end{array}$ & $\begin{array}{l}\text { Notice and severance pay for } \\
\text { no fault individual dismissal } \\
(1 / 3)\end{array}$ & & \\
\hline $\begin{array}{l}\text { Definition of unfair di } \\
\text { Trial period }(1 / 4) \\
\text { Compensation }(1 / 4) \\
\text { Reinstatement }(1 / 4)\end{array}$ & & Difficulty of dismissal (1/3) & & \\
\hline $\begin{array}{l}\text { Valid cases other the } \\
\text { Max number of succ } \\
\text { Max cumulated dura }\end{array}$ & $\begin{array}{l}e(1 / 2) \\
\text { tracts }(1 / 4)\end{array}$ & Fixed-term contracts $(1 / 2)$ & \multirow[t]{2}{*}{$\begin{array}{l}\text { Temporary contracts } \\
(5 / 12)\end{array}$} & \\
\hline $\begin{array}{l}\text { Types of work for wh } \\
\text { Restrictions on numk } \\
\text { Max cumulated dura }\end{array}$ & ewal (1/4) & $\begin{array}{l}\text { Temporary Work Agency } \\
(1 / 2)\end{array}$ & & \\
\hline $\begin{array}{l}\text { Definition of collectiv } \\
\text { Additional notification } \\
\text { Additional delays inv } \\
\text { Other special costs } t\end{array}$ & $\begin{array}{l}\text { al }(1 / 4) \\
\text { nents }(1 / 4) \\
\text { er }(1 / 4)\end{array}$ & \multicolumn{2}{|l|}{ Collective dismissals $(2 / 12$} & \\
\hline
\end{tabular}


Appendix 4 The frequency of different types of employment status in the Baltic States, selected CEE and EU countries, 2001.

\begin{tabular}{|c|c|c|c|c|c|c|c|c|c|}
\hline Country & $\begin{array}{c}\text { Self- } \\
\text { employed } \\
\text { and other }\end{array}$ & $\begin{array}{c}\text { 1.On an } \\
\text { unlimited } \\
\text { duration } \\
\text { (regular) } \\
\text { contract }\end{array}$ & $\begin{array}{c}\text { Strictness } \\
\text { of EPL } \\
\text { on } \\
\text { unlimited } \\
\text { contracts } \\
\end{array}$ & $(2) *(3)$ & $\begin{array}{c}\text { 2.On a } \\
\text { fixed } \\
\text { term } \\
\text { contract }\end{array}$ & $\begin{array}{c}\text { 3.On a } \\
\text { temporary } \\
\text { employment } \\
\text { agency } \\
\text { contract } \\
\end{array}$ & $\begin{array}{c}\text { Share of } \\
\text { temporary } \\
\text { work } \\
\text { together }\end{array}$ & $\begin{array}{l}\text { Strictness of } \\
\text { EPL on } \\
\text { temporary } \\
\text { employment }\end{array}$ & $\begin{array}{c}\text { Part-time } \\
\text { work }\end{array}$ \\
\hline & (1) & (2) & (3) & (4) & $(5)$ & (6) & $(7)$ & $(8)$ & $(9)$ \\
\hline Latvia & $13.7 \%$ & $55.4 \%$ & 2.3 & 1.3 & $20.1 \%$ & $5.7 \%$ & $25.8 \%$ & 2.10 & $10 \%$ \\
\hline Lithuania & $19.7 \%$ & $62.9 \%$ & 3.0 & 1.9 & $13.8 \%$ & $0.4 \%$ & $14.2 \%$ & 1.40 & $11 \%$ \\
\hline Estonia & $10.1 \%$ & $75.6 \%$ & 3.1 & 2.3 & $10.7 \%$ & $1.2 \%$ & $11.9 \%$ & 1.40 & $8 \%$ \\
\hline Baltic States & $14.5 \%$ & $64.6 \%$ & 2.8 & 1.8 & $14.9 \%$ & $2.4 \%$ & $17.3 \%$ & 1.63 & $9 \%$ \\
\hline Bulgaria & $17.4 \%$ & $56.4 \%$ & 2.8 & 2.0 & $20.7 \%$ & $1.4 \%$ & $14.5 \%$ & 2.70 & $10 \%$ \\
\hline Czech Republic & $15.9 \%$ & $72.1 \%$ & 2.8 & 2.0 & $9.5 \%$ & $0.9 \%$ & $10.4 \%$ & 0.50 & $8 \%$ \\
\hline Hungary & $17.4 \%$ & $73.4 \%$ & 2.1 & 1.5 & $8.4 \%$ & $0.0 \%$ & $8.4 \%$ & 0.60 & $6 \%$ \\
\hline Poland & $33.5 \%$ & $54.8 \%$ & 2.2 & 1.2 & $7.8 \%$ & $2.5 \%$ & $10.3 \%$ & 1.00 & $6 \%$ \\
\hline Slovakia & $12.7 \%$ & $75.0 \%$ & 2.6 & 2.0 & $10.6 \%$ & $0.8 \%$ & $11.4 \%$ & 1.40 & $7 \%$ \\
\hline Slovenia & $21.9 \%$ & $66.7 \%$ & 3.4 & 2.3 & $10.1 \%$ & $0.0 \%$ & $10.1 \%$ & 2.40 & $9 \%$ \\
\hline CEEC average & $18.0 \%$ & $65.8 \%$ & 2.7 & 1.8 & $12.4 \%$ & $1.4 \%$ & $13.0 \%$ & 1.50 & $8.2 \%$ \\
\hline $\mathrm{EU}$ & $16.6 \%$ & $68.1 \%$ & 2.6 & 1.8 & $8.3 \%$ & $1.8 \%$ & $10.1 \%$ & 2.3 & $18 \%$ \\
\hline
\end{tabular}

Source: Authors calculations; European Foundation for the Improvement of Living and Working Condition (2001); Franco, Jouhette (2002)

Note. The numbers are based on a survey of 1000 respondents in each of the candidate countries. The numbers for the candidate countries generally exceed those provided by the national statistics and Eurostat, however general cross-country variation is the same. 